\title{
Bacteria in the ECHAM5-HAM global climate model
}

\author{
A. Sesartic ${ }^{1}$, U. Lohmann ${ }^{1}$, and T. Storelvmo ${ }^{2}$ \\ ${ }^{1}$ ETH Zurich, Institute for Atmospheric and Climate Science, 8092 Zurich, Switzerland \\ ${ }^{2}$ Department of Geology and Geophysics, Yale University, New Haven (CT), USA
}

Correspondence to: A. Sesartic (ana.sesartic@env.ethz.ch)

Received: 27 November 2010 - Published in Atmos. Chem. Phys. Discuss.: 18 January 2011

Revised: 3 September 2012 - Accepted: 11 September 2012 - Published: 25 September 2012

\begin{abstract}
Some bacteria are among the most active ice nuclei found in nature due to the ice nucleation active proteins on their surface, which serve as active sites for ice nucleation. Their potential impact on clouds and precipitation is not well known and needs to be investigated. Bacteria as a new aerosol species were introduced into the global climate model (GCM) ECHAM5-HAM. The inclusion of bacteria acting as ice nuclei in a GCM leads to only minor changes in cloud formation and precipitation on a global level, however, changes in the liquid water path and ice water path are simulated, specifically in the boreal regions where tundra and forests act as sources of bacteria. Although bacteria contribute to heterogeneous freezing, their impact is reduced by their low numbers compared to other heterogeneous IN. This result confirms the outcome of several previous studies.
\end{abstract}

\section{Introduction}

Primary biological aerosol particles (PBAP, also called bioaerosols) are airborne particles that are either alive, carry living organisms or are released by them (Ariya and Amyot, 2004). A prominent example of PBAP are bacteria, on which we focus our research.

The presence of bacteria in the troposphere and even in the stratosphere has long been established by a variety of aerobiological research (Wainwright et al., 2003; Morris et al., 2011). Most of that research has however focused on issues related to health hazards, while ignoring their impacts on cloud formation and the hydrological cycle.

Bacteria have been shown in laboratory studies to be efficient ice nuclei (IN) and it has been suggested from different sides that bacteria which act as IN or cloud condensation nuclei $(\mathrm{CCN})$ in the atmosphere could impact the global dis- tribution of clouds and precipitation (Schnell and Vali, 1972, 1973; Yankofsky et al., 1981a,b; Levin and Yankofsky, 1988; Sands et al., 1982; Bauer et al., 2003; Diehl et al., 2006; Morris et al., 2004, 2011; Sun and Ariya, 2006).

Bacteria are ubiquitous and can enter the atmosphere as aerosol particles from almost all surfaces (Jones and Harrison, 2004). Once in the air, they can be carried upward by vertical updraughts. They have relatively long atmospheric residence times on the order of several days (Morris et al., 2011). They can be transported by wind over long distances (Bovallius et al., 1978b; Prospero et al., 2005) before being removed by wet scavenging (either in-cloud or belowcloud), or by dry deposition onto surfaces. Burrows et al. (2009b) summarised that mean concentrations in ambient air are likely to be at least $1 \times 10^{4}$ cells $\mathrm{m}^{-3}$ over land, while concentrations over ocean may be two to three orders of magnitude lower than over land and were therefore excluded in this study.

It is estimated that on a global average in the lower troposphere or near the surface, $25 \%$ of the total mass concentration of atmospheric aerosols is provided by primary bioaerosols (Jaenicke et al., 2007). Over biomes with high vegetation density such as the Amazon rainforest, bioaerosols account for as much as $74 \%$ of the total aerosol mass concentration near the surface (Graham et al., 2003), with fungal spores contributing 30-50\% (Matthias-Maser and Jaenicke, 1995). Even in marine air masses, the contribution of bioaerosols by both number concentration and volume amounts to 10-20\% (Gruber et al., 1998) for particles with a radius $>0.2 \mu \mathrm{m}$.

The highest number concentration of bacteria in the atmosphere is reached during summer, as this is the season with most abundant vegetation coverage that provides a habitat for leaf-dwelling bacteria 
(Amato et al., 2007; Tong and Lighthart, 2000). Bacteria which act as IN are gram-negative, which means that they have an outer membrane containing lipopolysaccharide chains on which lipoproteins are attached (Brock et al., 2000). Their surface area is therefore substantially enlarged and provides more potential active sites where ice nucleation is expected to take place.

In particular, Pseudomonas sp. is a bacterial strain which is an excellent CCN/IN. It is commonly associated with plants as a pathogen living on the leaf surface. Its ice nucleation activity is conferred by a single gene (inaZ) that encodes the outer membrane InaZ protein. Individual InaZ proteins cannot serve as IN, but form large, homogeneous aggregates that collectively orient water molecules into a conformation mimicking the crystalline structure of ice, thereby catalysing ice formation (Baertlein et al., 1992). It has also been shown that there are ice nucleation active fungi (Pouleur et al., 1992; Iannone et al., 2011) and pollen (Diehl et al., 2001, 2002; von Blohn et al., 2005), though they initiate freezing at colder temperatures than bacteria do.

Aircraft observations from the campaign Ice in Clouds Experiment - Layer-clouds (ICE-L) conducted in Wyoming in 2007 showed that biological particles were present in the residual material from heterogeneously nucleated ice crystals (Pratt et al., 2009). Furthermore, biological ice nuclei were found to be present in concentrations of up to about 500 particles per litre of freshly fallen snow water equivalent (Christner et al., 2008).

Ice nucleation active bacteria can catalyse the immersion freezing of supercooled water at temperatures as warm as $-2{ }^{\circ} \mathrm{C}$ due to the ice nucleation activating protein InaZ (Schnell and Vali, 1972; Maki et al., 1974; Yankofsky et al., 1981b; Möhler et al., 2008). Šantl Temkiv et al. (2009) found $12 \%$ of bacteria in rain samples to be IN active. A recent contribution to the 11th General Meeting of the American Society for Microbiology by Alex Michaud from Montana State University, showed that the ice in the center of hail stones contained up to 1000 bacteria cells per millilitre of melted hail (Michaud et al., 2011).

Diehl et al. (2006) and Diehl and Wurzler (2004) provide parametrisations for the contact and immersion freezing efficiencies of bacteria that can be used together with those for other bioaerosols, mineral dust and soot. Based on the experimental data from Levin and Yankofsky (1983), Diehl and Wurzler (2004) and Diehl et al. (2006), Fig. 1 shows the fraction of frozen droplets with a radius of $10 \mu \mathrm{m}$ for different temperatures and IN. Please note that the onset of freezing is depending also on the droplet size. Ice formation due to contact freezing starts at similar temperatures for bacteria and montmorillonite mineral dust particles, but then proceeds most rapidly for bacteria. For the case of immersion freezing, bacteria initiate freezing at approximately $10^{\circ} \mathrm{C}$ higher temperatures than mineral dust (montmorillonite and kaolinite) does. As bacteria nucleate ice already at such high temperatures, the ice particles forming on them have the longest

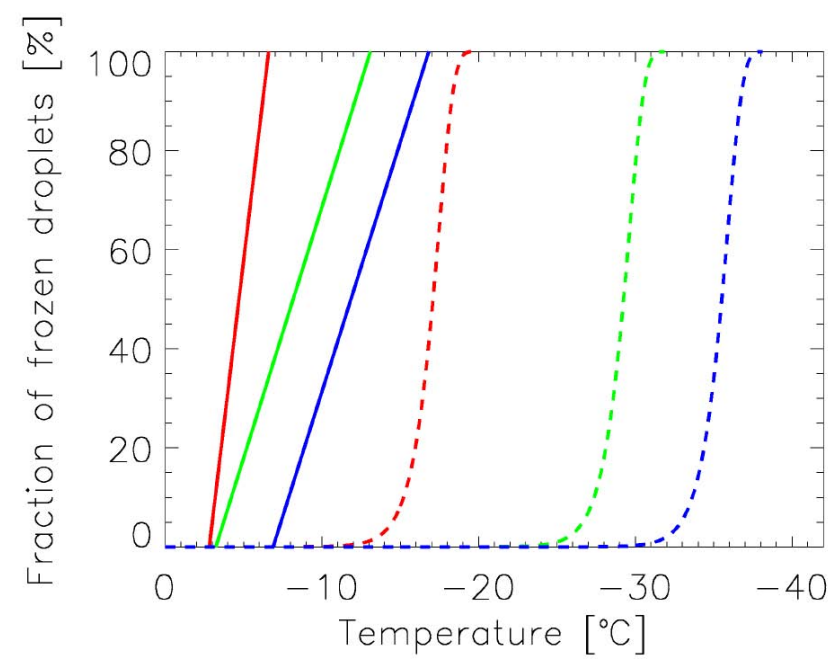

Fig. 1. Contact freezing frozen fractions (full lines) and immersion freezing frozen fractions (dashed lines) for a droplet radius of $10 \mu \mathrm{m}$ of bacteria (red), montmorillonite (green) and kaolinite (blue); from experimental data. Adapted from Lohmann and Diehl (2006).

possible time to grow in a cloud and the best chance to grow to precipitation sizes, which makes them interesting to investigate.

The interactions between aerosols and mixed-phase clouds are still uncertain, as reviewed by Lohmann and Feichter (2005). Recently there have been various modelling studies on potential impacts from biological aerosols on clouds, which have reached different conclusions (Grützun al., 2008; Phillips et al., 2009; Ariya et al., 2009; Burrows et al., 2009a; Diehl and Wurzler, 2010; Hoose et al., 2010a,b; Sun et al., 2010). While Hoose et al. (2010a) and Hoose et al. (2010b) do not find any significant impact of bioaerosols on clouds and precipitation, e.g. Phillips et al. (2009) state that cloud properties are altered by boosted bacterial concentrations. They agree however, that no impact is observed with realistic bacterial concentrations.

The overall aim of the present study is to examine the influence of bacteria on microphysical properties of stratiform clouds and precipitation on a global scale. In the following section, the global climate model and experimental design are described. Results from sensitivity tests are shown and discussed in the subsequent section.

\section{Model setup}

ECHAM5 is the fifth generation atmospheric general circulation model (GCM) that evolved from the model of the European Centre for Medium Range Weather Forecasting (ECMWF) and was further developed at the Max-Planck Institute for Meteorology (Roeckner et al., 2003). The model solves prognostic equations for vorticity, divergence, temperature and surface pressure using spherical harmonics with 
Table 1. Simulations.

\begin{tabular}{ll}
\hline Simulation & Description \\
\hline CTL & Control simulation. Bacteria are not IN active. \\
BT1 & Bacteria best-estimate emissions Burrows et al. (2009b), 1\% of bacteria IN active \\
BT10 & Bacteria best-estimate emissions Burrows et al. (2009b), 10\% of bacteria IN active \\
BT100 & Bacteria best-estimate emissions Burrows et al. (2009b), 100\% of bacteria IN active \\
100BT100 & Same as BT100 but with a hundredfold increase of bacteria emissions \\
\hline
\end{tabular}

triangular truncation. Water vapour, cloud liquid water and ice, as well as trace components, are transported using a semi-Lagrangian scheme (Lin and Rood, 1996) on a Gaussian grid. Prognostic equations for cloud water and ice follow Lohmann et al. (2007). The model includes the cirrus scheme of Kärcher and Lohmann (2002). Convective clouds and transport are based on the mass-flux scheme of Tiedtke (1989) with modifications following Nordeng (1994). The solar radiation scheme has 6 spectral bands (Cagnazzo et al., 2007) and the infrared has 16 spectral bands (Mlawer et al., 1997; Morcrette et al., 1998).

The GCM is coupled to the Hamburg Aerosol Model (HAM), which is described in detail by Stier et al. (2005) and most recently adapted by Lohmann and Hoose (2009). The aerosols are represented by seven log-normal modes, 4 internally mixed/soluble modes (nucleation (NS), Aitken (KS), accumulation (AS), and coarse (CS)) and 3 insoluble modes (Aitken (KI), accumulation (AI), and coarse (CI)). The median radius for each mode is calculated from the aerosol mass and number concentration in each mode. Aerosol mass and number are transferred from the insoluble to the internally mixed modes by the condensation of sulphuric acid and organic vapours, and coagulation with soluble aerosols.

The natural emissions of sea salt, dust, and dimethyl sulphate (DMS) from the oceans are calculated on-line, based on the meteorology of the model. Emissions for all other aerosol species are taken from the AEROCOM emission inventory, and are representative for the year 2000 (Dentener et al., 2006). The aerosol emissions and the removal processes of wet scavenging, sedimentation, and dry deposition are described in detail in Stier et al. (2005).

All results presented in this study are from simulations which have been integrated for one year, following a three months spin-up period. All simulations are nudged to the ECMWF ERA40 reanalysis data for the year 2000 (Simmons and Gibson, 2000), to minimise differences in dynamics between the different simulations. The nudging technique is described by Timmreck and Schulz (2004). The spectral resolution of all simulations is T42 which corresponds to $2.8125^{\circ} \times 2.8125^{\circ}$ horizontally, with 19 vertical levels from the surface up to $10 \mathrm{hPa}$ and a $30-\mathrm{min}$ time step. All simulations conducted in this study are summarised in Table 1.

\subsection{Bacteria in ECHAM5-HAM}

Bacteria in general and those with ice nucleating abilities in particular are commonly found on plant leaves (Lindemann et al., 1982; Hirano and Upper, 2000). Their concentration depends on the ecosystem they stem from.

The emission flux $F$ of bacteria is calculated in ECHAM5 according to

$$
F=\sum_{i=1}^{5} f_{i} F_{i}
$$

with $F_{i}$ being the bacterial number emission flux $\left[\mathrm{m}^{-2} \mathrm{~s}^{-1}\right]$ over a particular ecosystem, $f_{i}$ denoting the fractional coverage of a gridbox with a certain plant functional type, and $i$ standing for crops, grass, shrubs, forests and land ice. The fractions of the different ecosystems are obtained from the corresponding plant functional type area fractions of the JSBACH dynamic vegetation model (Raddatz et al., 2007). Burrows et al. (2009c) provided the observed near surface bacteria fluxes $\left(593 \mathrm{~m}^{-2} \mathrm{~s}^{-1}\right.$ over crops, $1123 \mathrm{~m}^{-2} \mathrm{~s}^{-1}$ over grassland, $8 \mathrm{~m}^{-2} \mathrm{~s}^{-1}$ over ice, $520 \mathrm{~m}^{-2} \mathrm{~s}^{-1}$ over shrubs, and $303 \mathrm{~m}^{-2} \mathrm{~s}^{-1}$ over forests), which were weighted by the area fraction of the respective ecosystems in the gridbox $\left(f_{i}\right)$.

Due to the limited available data on emissions of bacteria in the air, the ecosystem types available in JSBACH which are based on the Olson World Ecosystems dataset (Olson, 1992) were lumped into the aforementioned five groups. Crops and land ice are ecosystem types on their own, grass is comprised by $\mathrm{C} 3$ and $\mathrm{C} 4$ grasslands, while shrubs contains both raingreen and deciduous shrubs. The forest category is made of tropical broadleaf evergreen and deciduous trees, temperate broadleaf evergreen and deciduous trees, as well as coniferous evergreen and deciduous trees. This is of course a very crude assumption, but unfortunately, there are currently no better data available.

In order for bacteria to be incorporated into HAM (Stier et al., 2005) the number of aerosol modes was increased from 7 to 9 - adding an insoluble and soluble/mixed bioaerosol mode, that so far only contains bacteria as a new aerosol species (see Table 2). Bacteria are emitted initially in the insoluble bioaerosol mode, as IN active bacteria are assumed to be hydrophobic because these bacteria live primarily on solid surfaces on plant leaves, but also on stones, human skin, etc. 
Table 2. The modal structure of HAM with its aerosol species: sulphate $\left(\mathrm{SO}_{4}\right)$, black carbon (BC), organic carbon (OC), sea salt (SS), mineral dust (DU) and bacteria (BCT). The radius range of the aerosol particles in the respective mode is given by $r$.

\begin{tabular}{llll}
\hline Modes & Size range $[\mu \mathrm{m}]$ & mixed/soluble & insoluble \\
\hline Nucleation & $r \leq 0.005$ & $\mathrm{SO}_{4}$ & \\
Aitken & $0.005<r \leq 0.05$ & $\mathrm{SO}_{4}, \mathrm{BC}, \mathrm{OC}$ & $\mathrm{BC}, \mathrm{OC}$ \\
Accumulation & $0.05<r \leq 0.5$ & $\mathrm{SO}_{4}, \mathrm{BC}, \mathrm{OC}, \mathrm{SS}, \mathrm{DU}$ & $\mathrm{DU}$ \\
Coarse & $0.5<r \leq 1$ & $\mathrm{SO}_{4}, \mathrm{BC}, \mathrm{OC}, \mathrm{SS}, \mathrm{DU}$ & $\mathrm{DU}$ \\
Bioaerosol & $1<r$ & $\mathrm{SO}_{4}, \mathrm{BC}, \mathrm{OC}, \mathrm{SS}, \mathrm{DU}, \mathrm{BCT}$ & $\mathrm{DU}, \mathrm{BCT}$ \\
\hline
\end{tabular}

(McNamara et al., 1997). They can be transfered to the mixed mode by coating with $\mathrm{H}_{2} \mathrm{SO}_{4}$ and organic vapours, coagulation with sulphate, black carbon and organic carbon. Bacteria are additionally allowed to coagulate with dust, which has been observed for Saharan dust sampled over the Mediterranean and the Atlantic (Griffin, 2007; Kellog and Griffin, 2006).

The soluble accumulation and soluble coarse modes do not coagulate despite being soluble modes (Vignati et al., 2004) because the timescale for their coagulation is much longer than the timescale for coagulation between the Aitken and the accumulation mode. The same holds true for the coagulation between the insoluble accumulation and coarse modes. For the case of bioaerosols, they were allowed to coagulate with each other and with dust, as has been observed (e.g. Kel$\log$ and Griffin, 2006). Additionally, they coagulate with the soluble nucleation and soluble Aitken modes, mimicking the behaviour of dust.

The parametrisation for contact freezing of bacteria stems from Diehl et al. (2006) and that for immersion freezing from Diehl and Wurzler (2004). Deposition nucleation on bacteria is not considered, because observational data are missing for that process. Note that deposition freezing is also neglected for mineral dust, as it generally takes place at lower temperatures than the other heterogeneous freezing processes and is thought to be negligible in mixed-phase clouds.

Contact freezing is implemented into ECHAM according to Hoose et al. (2008) as follows:

$$
Q_{\mathrm{frz}, \mathrm{cnt}} \equiv-\left.\frac{\mathrm{d} N_{1}}{\mathrm{~d} t}\right|_{\mathrm{frz}, \mathrm{cnt}}=D_{\mathrm{ap}} 4 \pi r_{1} N_{\mathrm{a}, \mathrm{cnt}} N_{1}
$$

$Q_{\text {frz,cnt }}$ is the freezing rate via contact nucleation, $N_{1}$ the concentration of liquid droplets, $D_{\text {ap }}$ the size-dependent Brownian aerosol diffusivity, $r_{1}$ the volume-mean dropet radius and $N_{\mathrm{a}, \mathrm{cnt}}$ the number of contact nuclei. The latter is calculated as:

$$
\begin{aligned}
N_{\mathrm{a}, \mathrm{cnt}} & =\sum_{x} \operatorname{Max}\left(1, \operatorname{Min}\left(0,\left(-a_{x}(T-273.15 \mathrm{~K})-b_{x}\right)\right)\right) \\
& \times \frac{N_{\mathrm{cnt}, x}}{N_{\text {aer,insol }}}\left(N_{1}+N_{i}\right)
\end{aligned}
$$

with $x$ standing for montmorillonite mineral dust particles or bacteria. $N_{i}$ is the ice crystal number concentration, $N_{\text {aer,insol }}$ the total insoluble aerosol number concentration and $N_{\mathrm{cnt}, x}$ a number concentration of the maximum available contact ice nuclei of material $x$. The parameters $a_{x}$ and $b_{x}$ (see Table 3) are related to the aerosol's effectiveness to act as ice nuclei in the contact freezing mode as determined by Diehl et al. (2006). $T$ is the temperature in $\mathrm{K}$.

The immersion freezing parametrisation by Diehl and Wurzler (2004) describes the immersion freezing rate as:

$$
\begin{gathered}
Q_{\mathrm{frz}, \mathrm{imm}} \equiv-\left.\frac{\mathrm{d} N_{1}}{\mathrm{~d} t}\right|_{\mathrm{frz}, \mathrm{imm}}=N_{\mathrm{a}, \mathrm{imm}} \exp (273.15 \mathrm{~K}-T) \\
\frac{\mathrm{d} T}{\mathrm{~d} t} \frac{\rho q_{1}}{\rho_{\mathrm{l}}} \text { for } \frac{\mathrm{d} T}{\mathrm{~d} t}<0
\end{gathered}
$$

$\rho$ is the air density, $\rho_{1}$ the liquid water density and $q_{1}$ the cloud water mixing ratio. $N_{\mathrm{a}}$,imm is the number of immersion nuclei, which is related to a measured effectiveness $c_{x}$ (see Table 3, weighted by the number of potential ice nuclei of the respective material $x$ (this time denoting black carbon, montmorillonite and bacteria) and normalised by the total number of particles larger than $35 \mathrm{~nm}$ in radius (activation threshold according to Lin and Leaitch (1997) as implemented in ECHAM5-HAM by Lohmann et al., 2007).

$$
N_{\mathrm{a}, \mathrm{imm}}=\sum_{\mathrm{s}} c_{x} \frac{N_{\mathrm{imm}, x}}{N_{\mathrm{aer}, \mathrm{tot}}^{>35 \mathrm{~nm}}}
$$

The parametrisation for bacteria relies on data from Levin and Yankofsky (1983) who investigated the IN properties of the bacterial strain M1 (Yankofsky et al., 1981b). However, the reliability of these results is questionable, as the control freezing experiment conducted with purified water induced freezing at $-14^{\circ} \mathrm{C}$ instead of at $-35^{\circ} \mathrm{C}$, leading to the conclusion that the droplet generator used in those experiments might have been contaminated with ice nucleation inducing material. This is further supported by the fact, that when the same instrument as in the studies by Pitter and Pruppacher (1973) was used, their control experiments with pure water lead to the expected onset of homogeneous freezing at $-35^{\circ} \mathrm{C}$. Additionally, the number of IN per bacterial cell is unknown.

As there were no data available about shortwave and longwave radiative properties of bacteria, but they have a similar refractive index as sea salt (Wyatt, 1970; Ebert et al., 2002), the identical data as for sea salt (Fenn et al., 1981) were assumed for the optical properties of bacteria. The standard deviation of the bacterial distribution was set to 2 , equal to that of dust. The mean mass scavenging coefficient for bacteria scavenged by rain was set to $1 \mathrm{~kg} \mathrm{~m}^{-2}$ and to $5 \times 10^{-3} \mathrm{~kg} \mathrm{~m}^{-2}$ for bacteria scavenged by snow, as estimated from Seinfeld and Pandis (2006). Those are the same scavenging ratios as for dust. The mass of a bacterium in ECHAM was set to the average value $1^{-15} \mathrm{~kg}$ and its average density was calculated as being $1.2 \mathrm{~g} \mathrm{~cm}^{-3}$ from data available in Baron and Willeke (2001) and Hinds (1999). These values lead to a median diameter for bacteria of $2.5 \mu \mathrm{m}$. The size range of the 
Table 3. Parameters $a_{x}$ and $b_{x}$ for contact freezing (Diehl et al., 2006) and parameter $c_{x}$ for immersion freezing (Diehl and Wurzler, 2004) of black carbon (BC), montmorillonite (MON) and bacteria (BCT).

\begin{tabular}{llll}
\hline$x$ & $a_{x}\left(\mathrm{~K}^{-1}\right)$ & $b_{x}$ & $c_{x}\left(\mathrm{~m}^{-3}\right)$ \\
\hline BC & - & - & 0.00291 \\
MON & 0.1014 & 0.3277 & 32.3 \\
BCT & 0.2641 & 0.7423 & 6190000 \\
\hline
\end{tabular}

Table 4. Global bacteria emissions and burden calculated with ECHAM5 compared to the model results by Burrows et al. (2009a), Jacobson and Streets (2009) and Hoose et al. (2010b).

\begin{tabular}{lll}
\hline $\begin{array}{c}\text { Emissions } \\
{\left[\mathrm{Tg} \mathrm{yr}^{-1}\right]}\end{array}$ & $\begin{array}{l}\text { Burden } \\
{[\mathrm{Tg}]}\end{array}$ & Source \\
\hline 2.58 & 0.03 & ECHAM5 best estimate bacteria emissions \\
258 & 2.82 & ECHAM5 hundredfold bacteria emissions \\
$0.4-1.8$ & 0.0087 & Burrows et al. (2009a) \\
28.1 & $\mathrm{n} / \mathrm{a}$ & Jacobson and Streets (2009) \\
0.75 & 0.0043 & Hoose et al. (2010b) \\
\hline
\end{tabular}

most common bacteria lies between 0.5 and $5 \mu \mathrm{m}$ in diameter (Brock et al., 2000). While Hoose et al. (2010b) assume a diameter of $1 \mu \mathrm{m}$ in their calculations, our estimate is higher and similar to that of Burrows et al. (2009a) and represents an aggregate of several cells, as commonly found in the air (Lighthart, 1997). A sensitivity study was conducted, with a bacteria diameter of $1 \mu \mathrm{m}$. However, this led to virtually no changes in our model output.

\section{Results and discussion}

In the reference simulation (CTL) bacteria act only as passive tracer, i.e. bacteria are emitted and transported around the globe, but have no effects on the radiation budget, cloud microphysics and precipitation. In all the other simulations (cf. Table 1) bacteria are allowed to act as IN. In the simulations BT1, BT10 and BT100 bacteria best estimate emissions from Burrows et al. (2009c) are used and the fraction of bacteria acting as IN is varied from $1 \%$ to $10 \%$ and $100 \%$, respectively. The simulation 100BT100 represents an extreme case where all bacteria are assumed to be IN active, and their emission flux is increased by a factor of 100 . This factor of 100 is plausible for natural fluctuations of bacteria emissions due to seasonality, vegetation periods and microclimatic effects. Additionally, there is good reason to assume that the measured number of bacteria vastly underestimates the species diversity and quantity. This has been thoroughly discussed by many biology and biodiversity papers. To state an example, according to Horner-Devine et al. (2004) only less than $1 \%$ of the existing bacteria species have been described to date and according to Fahlgren et al. (2010), less
Table 5. Modelled global means of emissions and deposition of bacteria.

\begin{tabular}{llll}
\hline & $\begin{array}{l}\text { BT10 } \\
\text { Dust } \\
{\left[\mathrm{kg} \mathrm{m}^{-2} \mathrm{~s}^{-1}\right]}\end{array}$ & $\begin{array}{l}\text { BT10 } \\
\text { Bacteria } \\
{\left[\mathrm{kg} \mathrm{m}^{-2} \mathrm{~s}^{-1}\right]}\end{array}$ & $\begin{array}{l}\text { Bacteria } \\
{\left[\mathrm{kg} \mathrm{m}^{-2} \mathrm{~s}^{-1}\right]}\end{array}$ \\
\hline Emission & $4.55 \times 10^{-11}$ & $5.49 \times 10^{-13}$ & $5.49 \times 10^{-11}$ \\
Dry Deposition & $2.35 \times 10^{-11}$ & $1.70 \times 10^{-13}$ & $1.56 \times 10^{-11}$ \\
Wet Deposition & $2.19 \times 10^{-11}$ & $3.80 \times 10^{-13}$ & $3.93 \times 10^{-11}$ \\
Total Deposition & $4.55 \times 10^{-11}$ & $5.49 \times 10^{-13}$ & $5.49 \times 10^{-11}$ \\
\hline
\end{tabular}

than $1 \%$ of bacteria sampled are viable, therefore leading to an underestimation of the real bacteria concentration in the atmosphere. Phillips et al. (2009) also conducted simulations with bacteria numbers boosted up by two orders of magnitude in their research. Additionally, this allows us to investigate what would happen if their number concentration was assumed to be on the same order of magnitude as that of mineral dust aerosols.

The annual zonal mean vertical profiles of dust and bacteria number concentrations, as depicted in Fig. 2 show that there is transport of bacteria to the middle and upper troposphere. However, their number in the troposphere is two to three orders of magnitude lower than that of dust. By increasing bacteria emission a hundredfold, their number concentrations become comparable to those of dust, with average values of $1 \mathrm{~cm}^{-3}$. As can be seen from mixing ratios in Fig. 3, bacteria remain in the insoluble mode at high northern latitudes where there is less soluble materials to coagulate with, but are transferred into the soluble mode in regions where there are prominent anthropogenic emissions present.

The bacteria emissions and burdens as calculated with ECHAM are summarised in Table 4. The emissions are in the same order of magnitude but clearly exceed the upper end of the range of values calculated by Burrows et al. (2009a), they are higher than those shown by Hoose et al. (2010b) but lower than those of Jacobson and Streets (2009). The burden as well as the life-time of the bacteria in the atmosphere (4.2 days) is similar to Burrows et al. (2009a), suggesting a weaker removal of bacteria compared to results obtained by Hoose et al. (2010b). A hundredfold increase in emissions leads to a hundredfold increase of the bacterial burden as well.

The results from the BT10 simulation in Fig. 4 show the emission, deposition and burden of bacteria as compared to dust. It is evident from Fig. $3 \mathrm{~d}$ that the bacteria are transported over quite large distances. Their deposition is larger over areas with plenty of vegetation and high precipitation, e.g. the Amazon, the Congo basin, or South-East Asia. The bacteria burden is large over North-West Africa in a region with high emissions from the grasslands in a relatively dry climate.

As can be seen in Table 5, the emitted and deposited numbers of bacteria are two orders of magnitude smaller than 

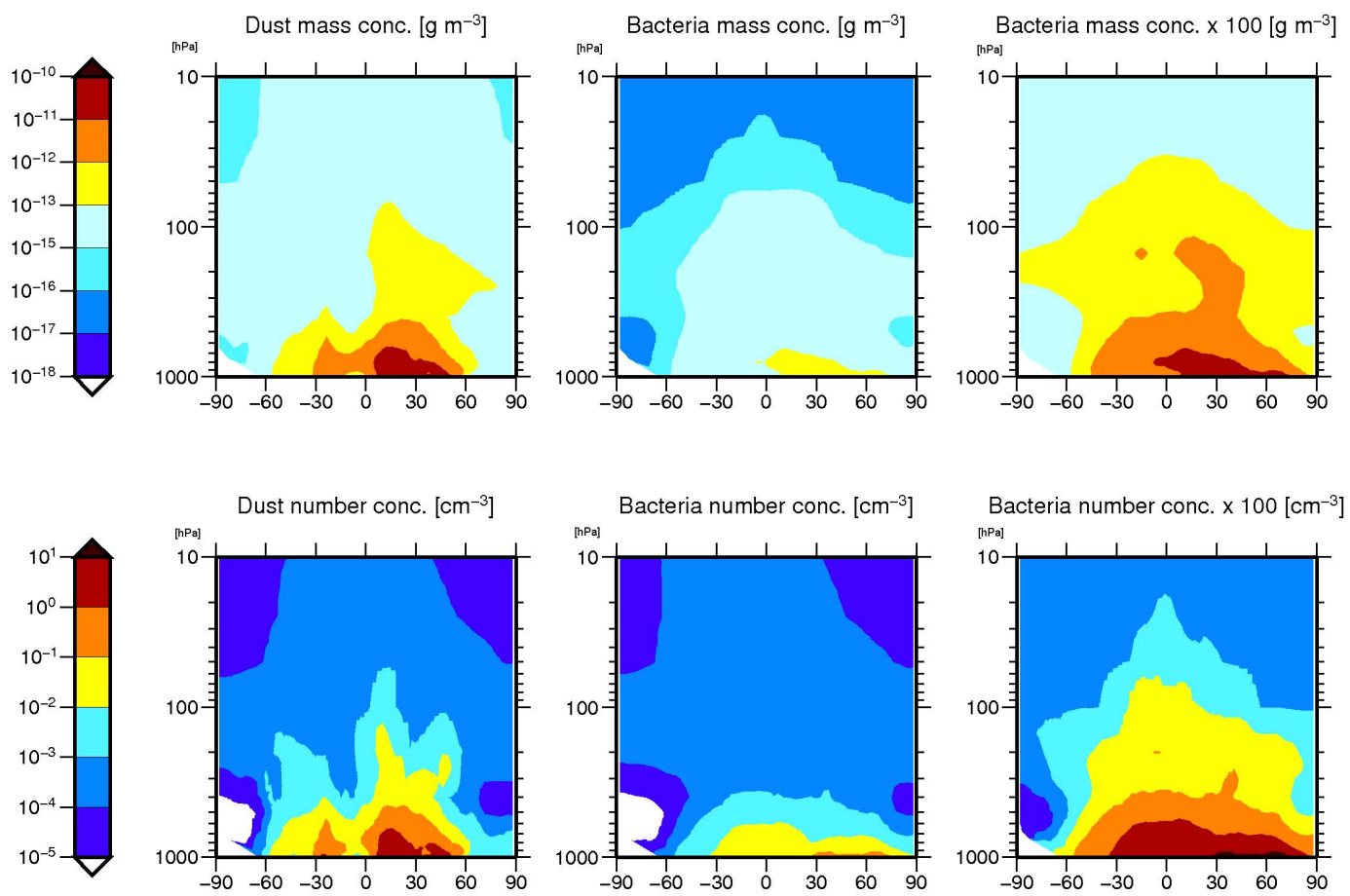

Fig. 2. Modelled (CTL and 100BT100, see Table 1 for description) annual zonal mean vertical profiles of dust and bacteria mass [ $\mathrm{gm}^{-3}$ ] and number concentrations in $\left[\mathrm{cm}^{-3}\right]$.
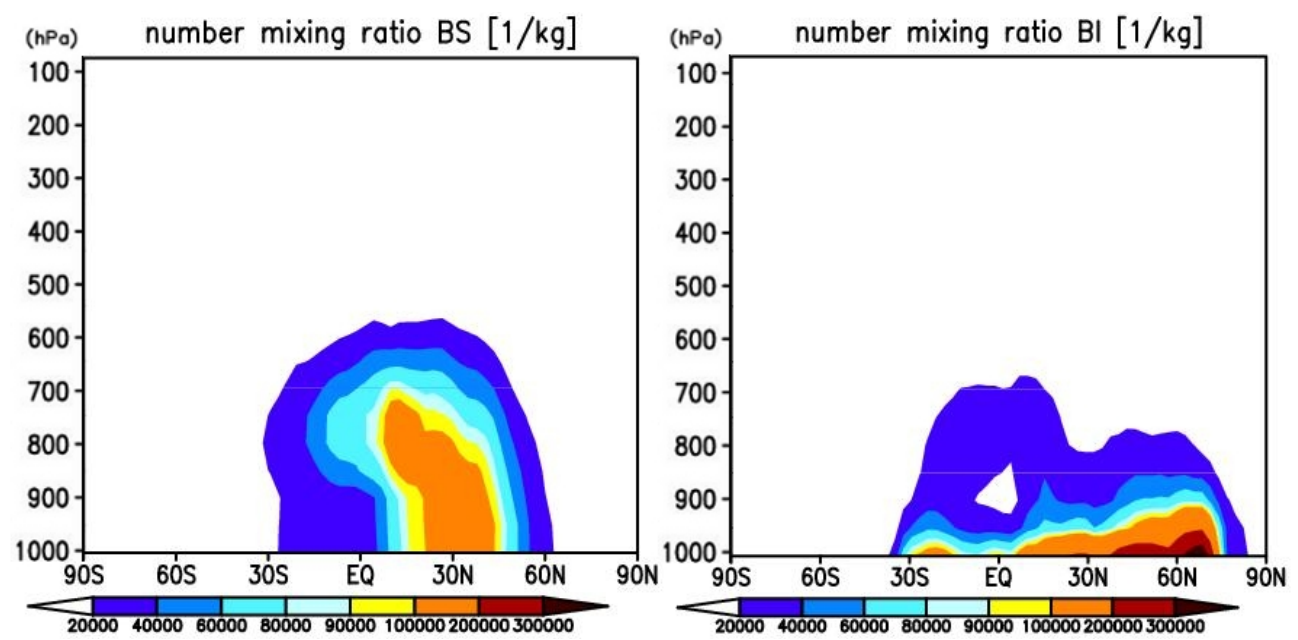

Fig. 3. Modelled (BT1, see Table 1 for description) annual zonal mean vertical profiles of bacteria soluble (BS) and insoluble (BI) number mixing ratios $\left[\mathrm{kg}^{-1}\right]$.

those of mineral dust. The simulation 100BT100 was therefore included in a sensitivity study in order to investigate the impact bacteria might have if they were as numerous as dust. While dust is deposited equally through dry and wet deposition, the primary pathway for removal of bacteria is via wet deposition. This is due to the fact that bacteria nucleate more readily than dust and due to their low density some bacteria can be lighter than large dust particles. Furthermore, dust is emitted primarily in dry regions where there is very little pre- cipitation and thus wet deposition, while the opposite is true for bacteria.

The simulated bacterial number concentrations were compared to observations at various locations in Fig. 5. In order to compare the model values with observations, the model values were interpolated to the location of the measurements and divided by a factor 100 in order to account for only $1 \%$ of bacteria being viable (Fahlgren et al., 2010), as is the case in observations. The comparability of point measurements 

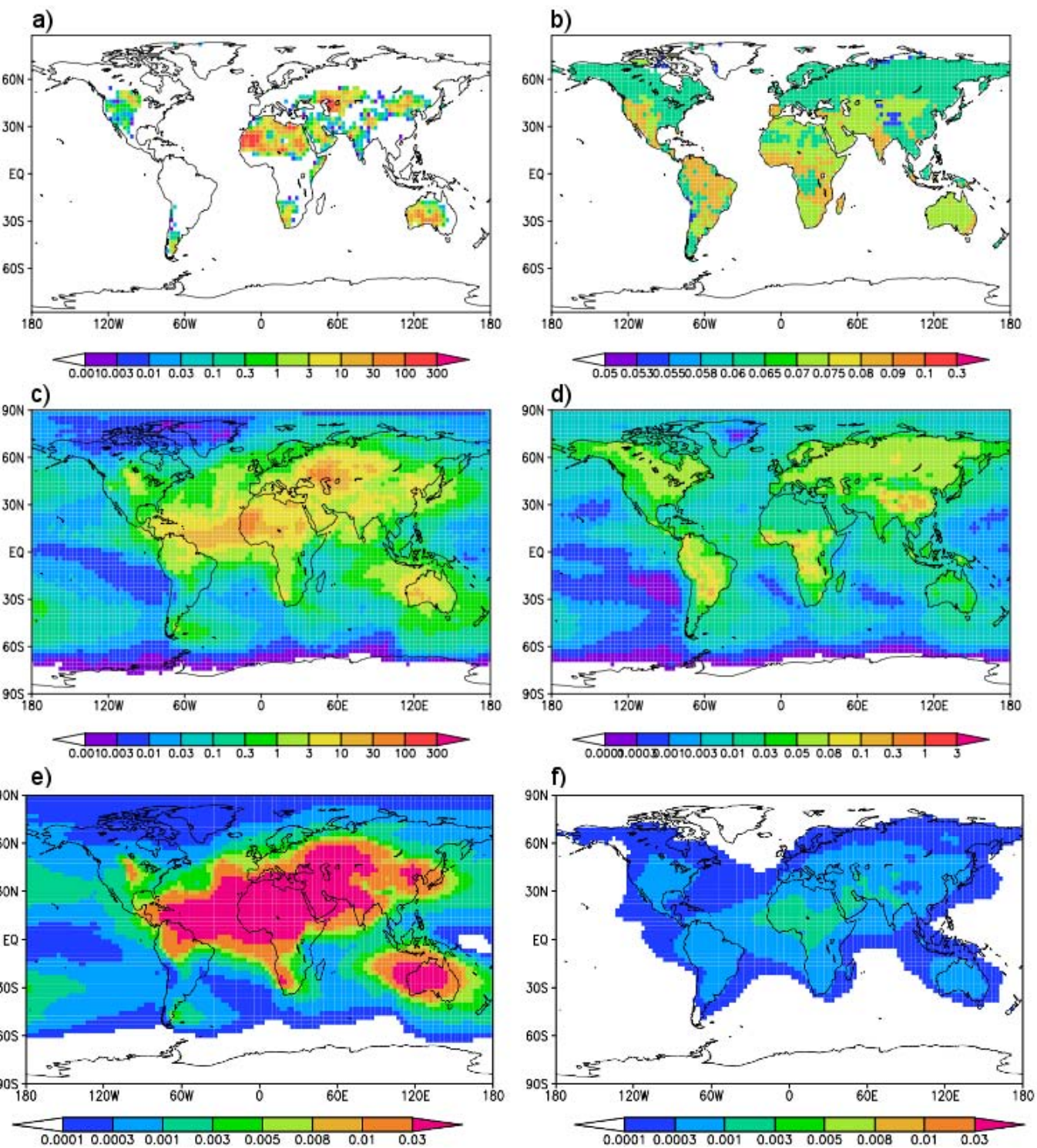

Fig. 4. Modelled (BT10, see Table 1 for description) global annual means of emission, deposition and burden of bacteria and mineral dust. (a) dust emission $\left[\mathrm{g} \mathrm{m}^{-2} \mathrm{yr}^{-1}\right]$ (b) bacteria emission $\left[\mathrm{g} \mathrm{m}^{-2} \mathrm{yr}^{-1}\right]$ (c) dust deposition $\left[\mathrm{g} \mathrm{m}^{-2} \mathrm{yr}^{-1}\right]$ (d) bacteria deposition $\left[\mathrm{g} \mathrm{m}^{-2} \mathrm{yr}^{-1}\right]$ (e) dust burden $\left[\mathrm{g} \mathrm{m}^{-2}\right]$ (f) bacteria burden $\left[\mathrm{g} \mathrm{m}^{-2}\right]$.

to global model data with grid sizes of $2.8^{\circ} \times 2.8^{\circ}$ is, however, limited. The standard deviation of the observational data is rather large, as the measurement methods differ for each location and the variability of bacteria concentrations is high. The model greatly underestimates both the mean observed bacteria concentrations and the variability in the bacteria concentrations. Standardised long-term observations with world-wide coverage are necessary for a more precise model evaluation. Such observations would help by providing a uniform database stemming from fixed measurement methods and thus reducing the errors. The representation of natural variability in a model could also be improved by a dynamic bacteria emission scheme or detailed observations distinguishing for example between different forest biomes. However, it is necessary to keep in mind that a GCM can never capture the exact natural variability of any quantity, no matter the detail of the emission data set, as each gridbox represents an average over several hundred kilometers.

Bacteria produce ice faster and earlier than dust, as can be seen from Fig. 1, shifting the ice nucleation from on dust to nucleation on bacteria. At the same time, there are much fewer bacteria than mineral dust aerosols available as IN. Consequently, the changes from CTL to BT1, BT10 and BT100 in the cloud droplet number concentration (CDNC), ice crystal number concentration (ICNC), precipitation, cloud cover, relative humidity, short-wave (SCF) and 


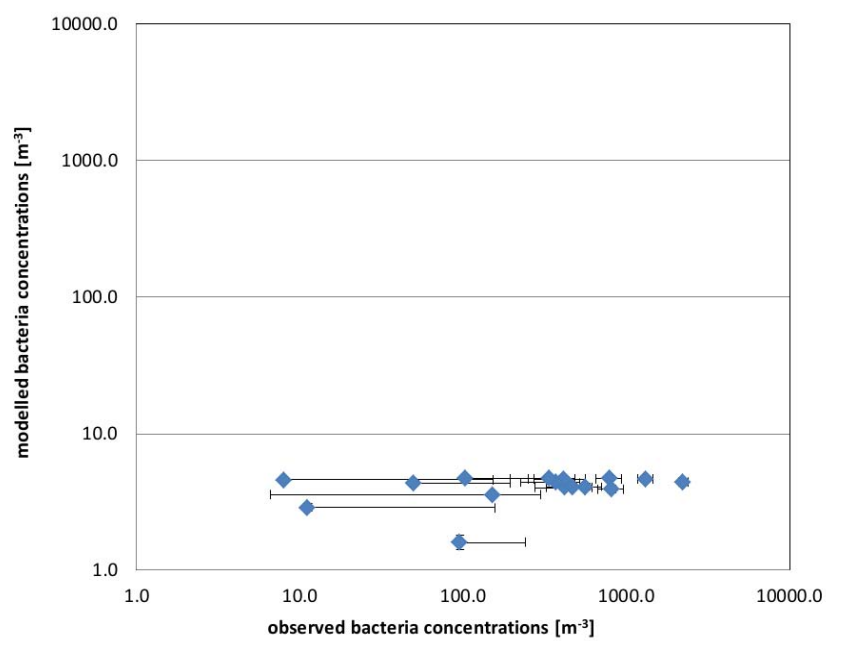

Fig. 5. Simulated bacteria concentrations at ground level, divided by factor 100 in order to account for viable bacteria, compared to observations. Observations are averages over different time periods, and the simulated data were interpolated to the measurement location. The bars indicate the standard deviation for all measurements at one location. Observations are taken from Bauer et al. (2002), Bovallius et al. (1978a), Bovallius et al. (1978b), Borodulin et al. (2005), Chen et al. (2001), DiGiorgio et al. (1996), Fang et al. (2007), Kelly and Pady (1954), Lindemann et al. (1982), Mouli et al. (2005), Negrin et al. (2007), Pastuszka et al. (2000), Rosas et al. (1994), Rüden et al. (1978), Schlesinger et al. (2006), Shaffer and Lighthart (1997), Tilley et al. (2001), and Vlodavets and Mats (1958).

long-wave cloud forcing (LCF), as well as the aerosol optical depth (AOD) remain small (cf. Table 6). However, one can see from the vertical profile in Fig. 6 and the vertically integrated difference in Fig. 7 that this is partly the result of averaging.

As Figs. 8 and 9 show, bacteria and mineral dust are similarly important for contact freezing. As the role of black carbon in contact freezing is not known yet, it only acts as immersion nuclei in ECHAM5. The contribution of black carbon to freezing is negligible. Both in contact and immersion freezing, bacteria initiate freezing at lower altitudes and thus at higher temperatures than mineral dust.

Mineral dust plays as stronger role for the immersion freezing in the BT1 simulation (Fig. 8). The influence of bacteria is limited to the equator and high northern latitudes where there are abundant bacteria sources from vegetation. Dust is the dominating freezing agent in the Southern Hemisphere, where there is less vegetation as a source for bacteria, but more dust sources with the Australian and Atacama deserts. In the BT10 simulation results as shown in Fig. 9 bacteria dominate the immersion freezing.

Bacteria contribute to total freezing more strongly than dust, especially in the immersion mode, while in contact mode they are more or less comparable. Again, we see an impact in northern latitudes and for immersion freezing around the lowest levels where freezing occurs. This confirms our hypothesis that the reason we see only small changes in cloud properties in simulations with and without bacteria (apart from high northern latitudes), is not that bacteria do not contribute to freezing, but that they largely replace dust particles acting as ice nuclei.

Nevertheless, the changes in IWP and LWP remain small, as can be seen from Fig. 7 and Table 6. Although bacteria contribute to heterogeneous freezing, their impact is reduced by their low numbers compared to other heterogeneous IN. While we reach the same conclusion as Hoose et al. (2010b) with CAM-Oslo (i.e. tiny effect overall), we reach it for different reasons. It seems that the cloud microphysics in ECHAM5 is such that because there is already mineral dust acting as IN, the effect of adding bacteria as IN is minor (as measured by changes in precipitation, LWP, IWP, radiation etc.).

There is a slight reduction in LWC and increase in IWC, which is expected, as bacteria are efficient IN. The IWC is slightly higher in the heterogeneous freezing regime, while the LWC is slightly lower, as can be seen in Fig. 6. The area of large changes in IWC in the Arctic in Fig. 6 is due to the fact that temperatures there are in the range of mixed-phase clouds $\left(0^{\circ} \mathrm{C}\right.$ to $\left.-35^{\circ} \mathrm{C}\right)$ for large parts of the year even at the surface, so the bacteria do not have to be transported high up into the atmosphere to have an impact in this region. Around the Arctic circle there are vast areas of tundra and boreal forests which are providing relatively high bacteria concentrations to the Arctic, which is also evident in the zonal mean bacteria concentration in Fig. 2.

We consider the simulation BT10 to be the best estimate, according to observations by Šantl Temkiv et al. (2009) which found $12 \%$ of bacteria in rain samples to be IN active. Even in this simulation, the change in LWP and IWP is small but non-negligible and a feature consistent throughout the simulations. As expected, the IWP increases while the LWP decreases due to the earlier onset of the Bergeron-Findeisen process, if bacteria are available as additional IN. As evident from Fig. 7, the change is especially pronounced on the northern hemisphere, where forests contribute to higher bacteria concentrations. The LWP reduction is most prominent in the storm-tracks due to more efficient precipitation formation. Overall the signal is consistent for different bacteria concentrations and IN activities.

Looking at global maps of LWP and IWP in Figs. 10 and 11 , respectively, LWP is generally lower over the continents, and especially over North America and Asia. Corresponding to the LWP decrease the IWP is increased over continents, specifically in the Arctic and over South America, where forests act as sources of bacteria.

For the extreme assumption of a 100-fold increase in bacteria emissions in the 100BT100 simulation, a considerable change can be observed (cf. Table 6). There is a $7 \%$ reduction in LWP between the 100BT100 and CTL case (cf. Fig. 7). As a result there is also significantly less 
Table 6. Yearly average values for the simulations CTL, BT1, BT10 and BT100 compared to observations (OBS). The table displays liquid water path (LWP), ice water path (IWP), total cloud cover (TCC), the vertically integrated cloud droplet number concentration (CDNC) and ice crystal number concentration (ICNC), total precipitation $(P)$, shortwave cloud forcing (SCF), longwave cloud forcing (LCF), radiation budget at the top of the atmosphere $F_{\text {net }}$ and aerosol optical depth (AOD). See Table 1 for the description of the simulation acronyms. Global averaged annual estimates and zonal mean estimated observational data are taken from the Global Precipitation Climatology Project (GPCP) for total precipitation $P_{\text {tot }}$ (Huffman et al., 1997; Adler et al., 2003). LWP stem from satellite (SSM/I) retrievals by Wentz (1997), Greenwald et al. (1993) and Weng and Grody (1994). IWP is derived from the International Satellite Cloud Climatology Project ISCCP data (Storelvmo et al., 2008). Cloud droplet number concentration $N_{1}$ retrievals from Han et al. (1998) is available for $50^{\circ} \mathrm{N}$ to $50^{\circ} \mathrm{S}$. Shortwave and longwave cloud forcing (SCF and LCF) are deduced from Kiehl and Trenberth (1997). The data of aerosol optical depth AOD are provided by Schulz et al. (2006) and S. Kinne (personal communication, 2008). Cloud cover observations are derived from observations of ISCCP (Rossow and Schiffer, 1999), surface observations collected by Hahn et al. (1995) and satellite observations estimated by Stubenrauch and Kinne (2009).

\begin{tabular}{|c|c|c|c|c|c|c|}
\hline ECHAM5.5- & CTL & BT1 & BT10 & BT100 & 100BT100 & OBS \\
\hline $\mathrm{LWP}\left[\mathrm{g} \mathrm{m}^{-2}\right]$ & 56.61 & 56.24 & 56.09 & 55.78 & 52.80 & $48-83$ \\
\hline IWP $\left[\mathrm{g} \mathrm{m}^{-2}\right]$ & 6.965 & 6.976 & 6.990 & 7.007 & 7.019 & 29 \\
\hline $\mathrm{TCC}[\%]$ & 60.14 & 60.16 & 60.21 & 60.18 & 60.12 & $65-75$ \\
\hline $\mathrm{CDNC}\left[10^{10} \mathrm{~m}^{-2}\right]$ & 3.415 & 3.397 & 3.401 & 3.403 & 3.192 & 4 \\
\hline $\operatorname{ICNC}\left[10^{10} \mathrm{~m}^{-2}\right]$ & 0.124 & 0.123 & 0.122 & 0.121 & 0.096 & - \\
\hline$P\left[\mathrm{~mm} \mathrm{day}^{-1}\right]$ & 2.839 & 2.840 & 2.840 & 2.841 & 2.856 & 2.74 \\
\hline $\mathrm{SCF}\left[\mathrm{W} \mathrm{m}{ }^{-2}\right]$ & -48.81 & -48.76 & -48.77 & -48.71 & -47.16 & -47 to -50 \\
\hline $\mathrm{LCF}\left[\mathrm{W} \mathrm{m} \mathrm{m}^{-2}\right]$ & 26.33 & 26.33 & 26.33 & 26.29 & 25.75 & $2-30$ \\
\hline AOD & 0.117 & 0.117 & 0.117 & 0.117 & 0.187 & $0.15-0.18$ \\
\hline
\end{tabular}

solar radiation reflected back to space by clouds $(\triangle \mathrm{SCF}=$ $1.65 \mathrm{~W} \mathrm{~m}^{2}$ ). This change in cloud radiative forcing is almost exactly the same as the entire increase in the greenhouse effect due to anthropogenic $\mathrm{CO}_{2}$ since pre-industrial times (Forster et al., 2007). There is also more longwave radiation escaping to space $\left(\triangle \mathrm{LCF}=0.58 \mathrm{~W} \mathrm{~m}^{2}\right)$ because of the reduced number of ice crystals so that the net change is slightly more than $1 \mathrm{~W} \mathrm{~m}^{2}$, which is still a rather strong effect. Additionally, bacteria have an enormous effect on the AOD in the 100BT100 simulation, leading to a $59 \%$ increase by direct reflection of solar radiation.

\section{Conclusions}

Bacteria as a new aerosol particle mode were introduced into ECHAM5-HAM and their emissions, transport and impact on clouds and precipitation were investigated.

It was shown that bacteria can successfully be transported to the middle and upper troposphere, however, their number concentration is two to three orders of magnitude lower than that of dust. The bacteria emissions and burdens calculated with ECHAM are comparable to those in previous studies and it could be shown that they are successfully transported over large distances. Comparison with the few available observations shows that the modelled emission fluxes are on the same order of magnitude as the observations. While the mean observed bacteria concentrations are captured by the model, the model greatly underestimates the variability in the bacteria concentrations if the results are scaled to reflect only viable bacteria. Standardised long-term observations with world-wide coverage are necessary for a more pre- cise model evaluation. Hereby they need to distinguish more precisely between different biomes especially between tropical, temperate and boreal forests. A dynamic bacteria emission scheme depending on the vegetation properties would also help to improve the representation of natural variability in the models.

Concerning their microphysical properties, the changes compared to a no-bacteria reference simulation are minor. The reason for this is not that bacteria do not contribute to freezing, but that they largely replace dust particles acting as ice nuclei. Changes in the liquid water path and ice water path can be observed, specifically in the boreal regions of the Arctic circle where tundra and forests act as sources of bacteria. Those changes are small but non-negligible and a feature consistent throughout the simulations.

A sensitivity study with the extreme assumption of a 100fold increase in bacteria emissions leads to a $7 \%$ reduction in the LWP as compared to the reference case. Consequently, there is also less solar radiation reflected back to space by clouds leading to a cloud radiative forcing which corresponds nearly to the increase in the greenhouse effect due to anthropogenic $\mathrm{CO}_{2}$ since pre-industrial times. At this point we do not know enough about bacteria emissions to rule out that simulation as unrealistic. However, to the best of our current knowledge, the influence of bacteria on the global climate appears small.

More observational data about bacterial emissions and deposition, as well as in-situ measurements inside clouds and vertical profiles of bacteria concentration are needed for a better comparison of model results with observations. Past measurements of ambient bacterial concentrations have 

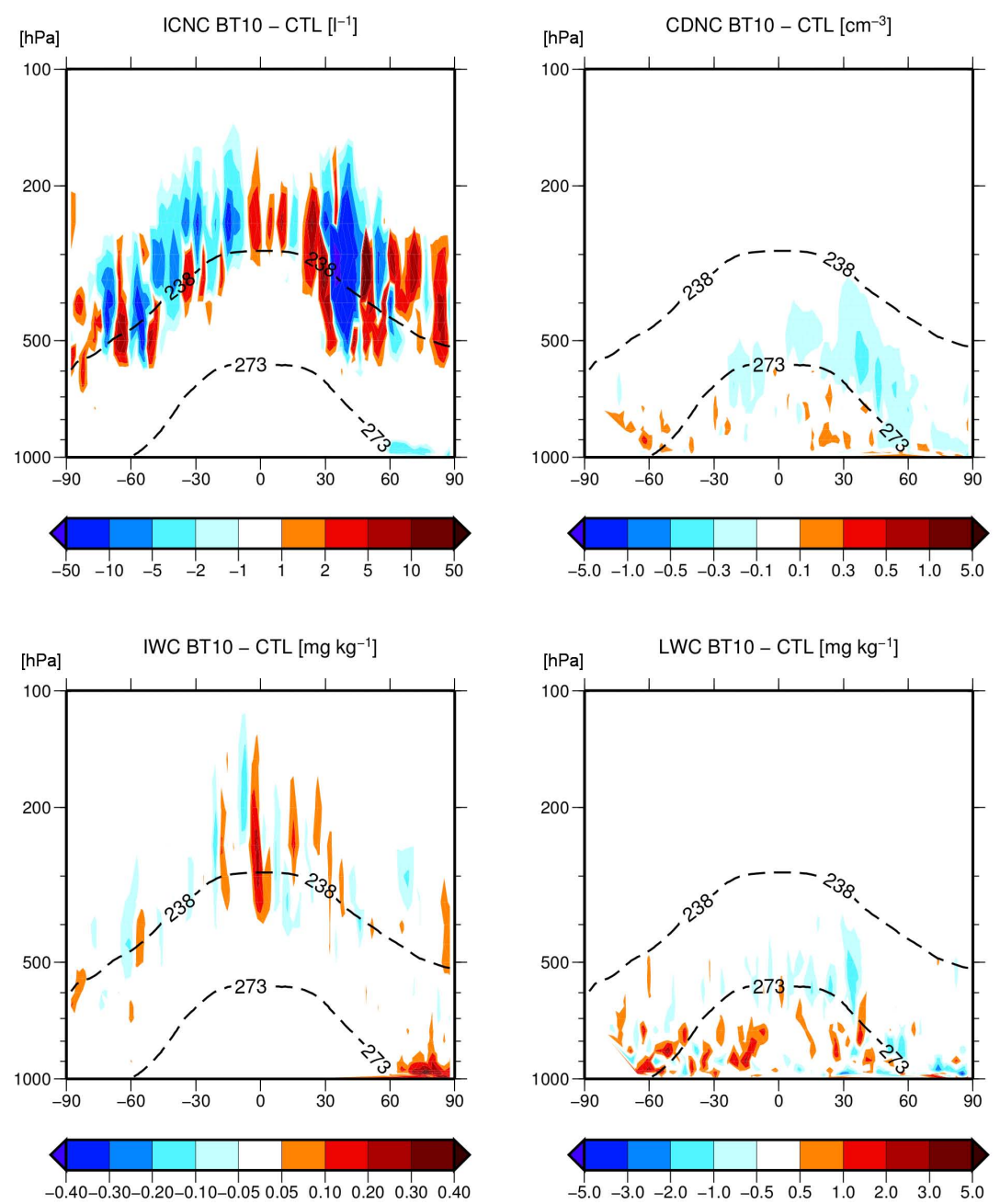

Fig. 6. Modelled annual zonal mean vertical profiles of the difference between the simulations with $10 \%$ of bacteria acting as IN (simulation BT10) and no bacteria acting as IN (simulation CTL), for the ice water content (IWC), ice crystal number concentration (ICNC), liquid water content (LWC) and cloud droplet number concentration (CDNC).
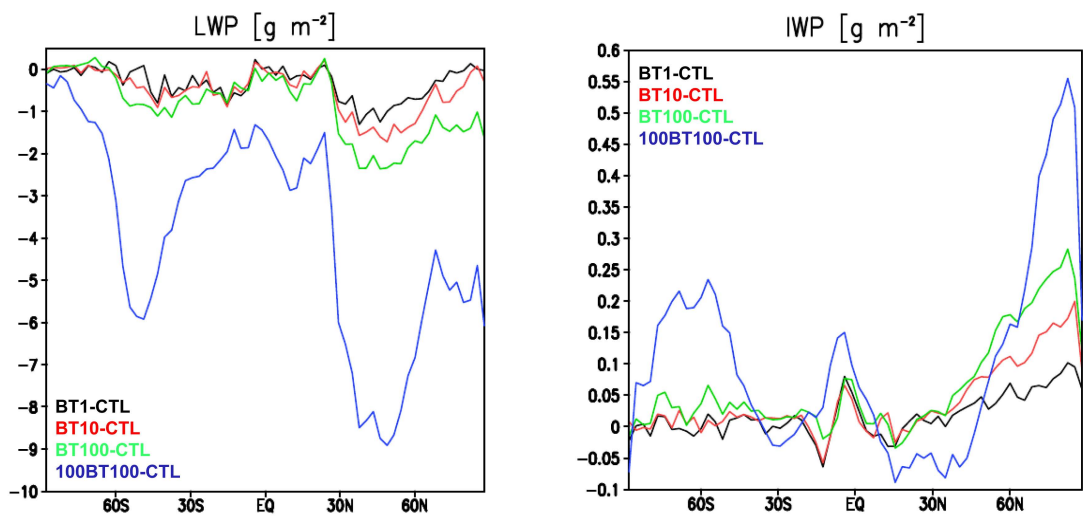

Fig. 7. Modelled annual zonal mean vertically integrated difference between the simulations with $1 \%$ of bacteria acting as IN (simulation BT1, black line), $10 \%$ of bacteria acting as IN (simulation BT10, red line), $100 \%$ of bacteria acting as IN (simulation BT100, green line), $100 \%$ of hundredfold bacteria acting as IN (simulation 100BT100, blue line) and no bacteria acting as IN (simulation CTL), for the ice water path (IWP) and liquid water path (LWP), respectively. 

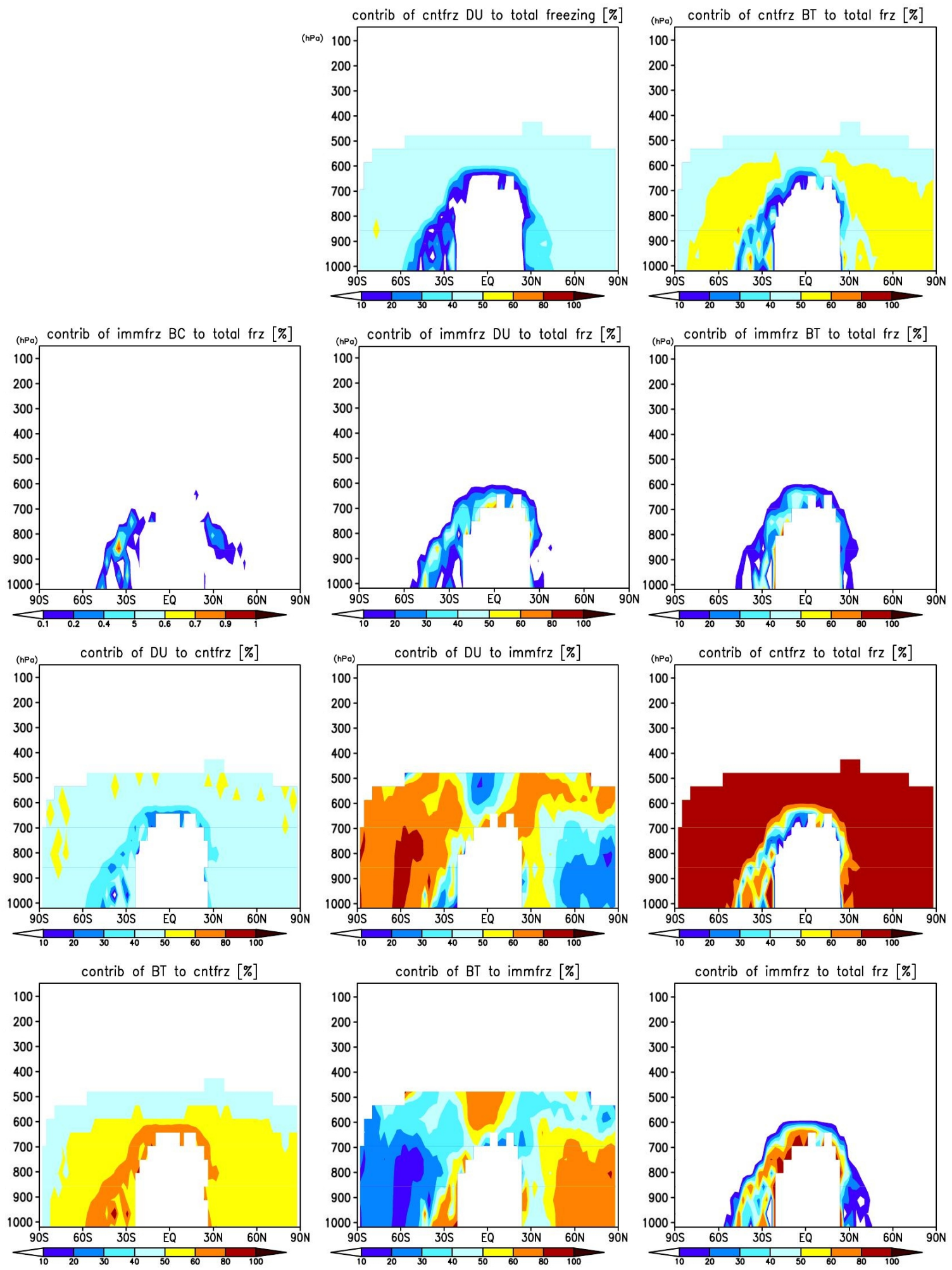

Fig. 8. Modelled annual zonal mean latitude vs. pressure cross sections of the percentage fraction of the different freezing mechanisms from simulation BT1 for bacteria, mineral dust and black carbon. Please note the different scale for black carbon. 

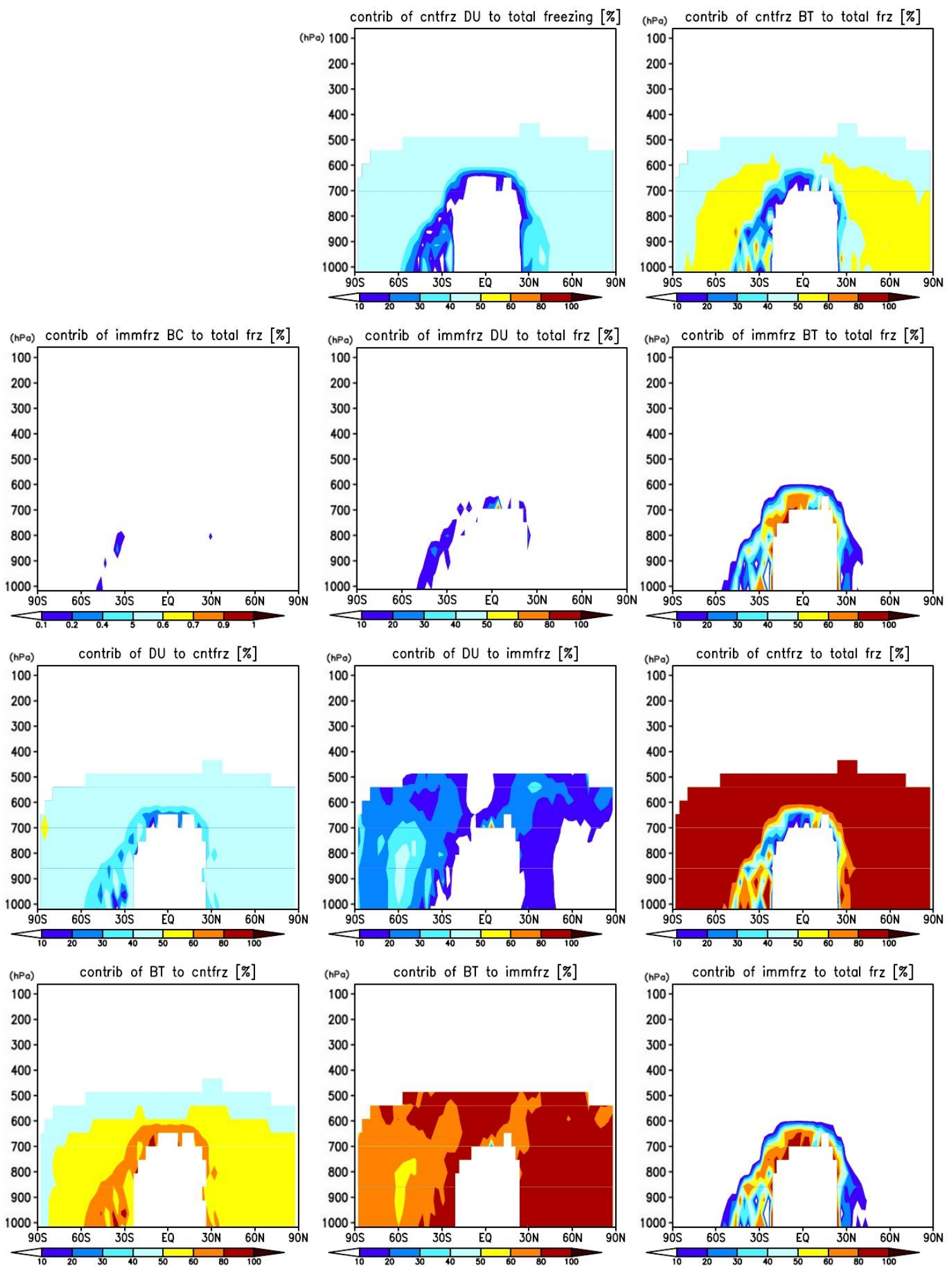

Fig. 9. Modelled annual zonal mean latitude vs. pressure cross sections of the percentage fraction of the different freezing mechanisms from simulation BT10 for bacteria, mineral dust and black carbon. Please note the different scale for black carbon. 

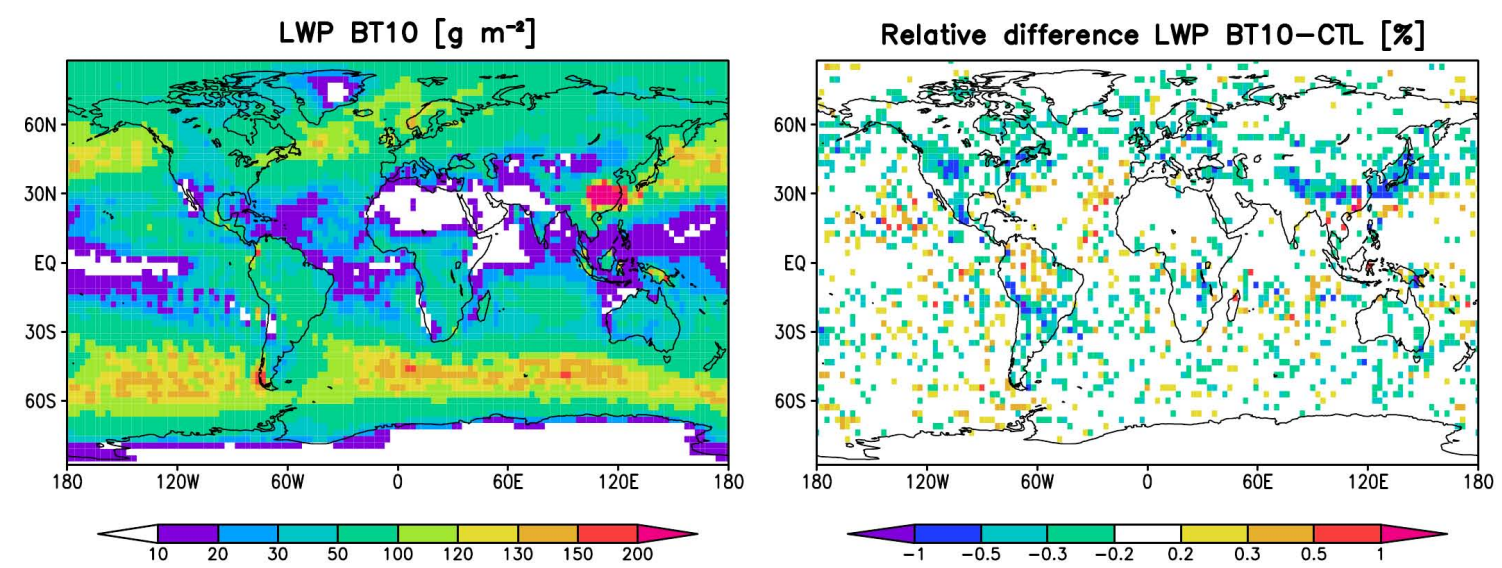

Fig. 10. Modelled annual global mean liquid water path (LWP), and the difference between BT10 and CTL.
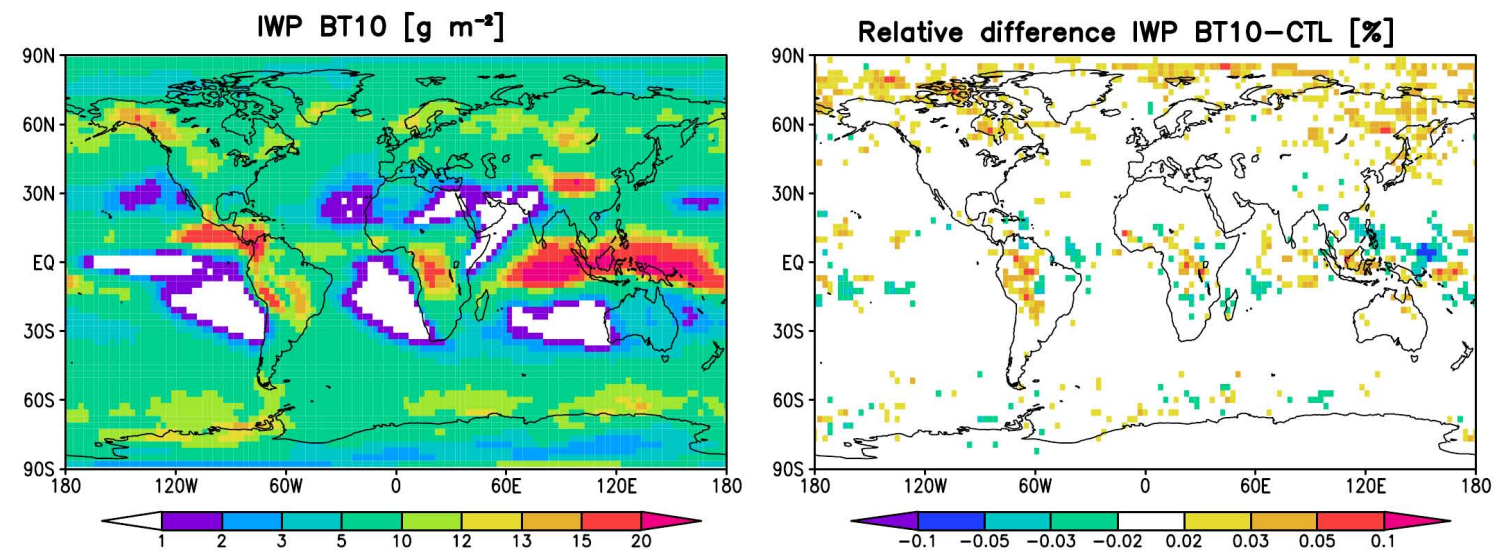

Fig. 11. Modelled annual global mean ice water path (IWP), and the difference between BT10 and CTL.

focused on point sources, thus neglecting many ecosystems, especially the less accessible and remote ones (e.g. tropical rainforests, wetlands, deserts, tundra). Especially the forests include a variety of diverse ecosystems and it would be meaningful to distinguish the various forest types in a future study. In order to get a consistent picture of bioaerosol sources, all biomes need to be considered in the observations. Likewise, only few measurements have been made over oceans. As oceans cover a large area of our planet it is important to clarify if biological particle fluxes from marine sources make a significant contribution to the high IN concentrations observed in these regions as stated by Schnell and Vali (1976) and Bigg et al. (2004). Long-term observations of bioaerosols with a world wide coverage could help to bridge this gap.

There are currently several uncertainties constraining the modelling of the impact of bacteria on climate and precipitation, for example their exact emissions, size distributions, ice nucleation active fractions etc. Additional data is also needed on the impact of coating and ageing on the bacte- rial IN-ability, as well as some fundamental data on density, aerodynamic diameter and refractive index of the bacteria.

Global modelling results suggest that bioaerosols have only a minor impact on the Earth's climate, but might show regional effects. Further modelling research should therefore focus on regional and local effects of bioaerosols, especially in highly vegetated regions, like tropical forests, as a potential impact of bacteria on local climate might be expected.

Acknowledgements. The authors are grateful to Sylvaine Ferrachat and Declan O'Donnell for their technical support with ECHAM5; Susannah Burrows for sharing and discussing data; Karoline Diehl, Corinna Hoose and Elisabetta Vignati for additional information on their papers; Stephanie Jess, Felix Lüönd, Luis Ladino Moreno, Cédric Chou and Andreas Fischlin for helpful comments and discussions; Pierre Amato, Corinna Hoose and an anonymous referee for their in-depth reviews.

Edited by: M. Krämer 


\section{References}

Adler, R., Huffman, G., Chang, A., Ferraro, R., Xie, P., Janowiak, J., Rudolf, B., Schneider, U., Curtis, S., Bolvin, D., Gruber, A., Susskind, J., Arkin, P., and Nelkin, E.: The version-2 global precipitation climatology project (GPCP) monthly precipitation analysis (1979-present), J. Hydrometeorol., 4, 1147-1167, 2003.

Amato, P., Parazols, M., Sancelme, M., Mailhot, G., Laj, P. and Delort, A-M.: An important oceanic source of micro-organisms for cloud water at the Puy de Dôme (France), Atmos. Environ., 41, 8253-8263, 2007.

Ariya, P. and Amyot, M.: New Directions: The role of bioaerosols in atmospheric chemistry and physics, Atmos. Environ., 38, 12311232, doi:10.1016/j.atmosenv.2003.12.006, 2004.

Ariya, P., Sun, J., Eltouny, N. A., Hudson, E. D., Hayes, C. T., and Kos, G.: Physical and chemical characterization of bioaerosols implications for nucleation processes, Int. Rev. Phys. Chem., 28, 1-32, doi:10.1080/01442350802597438, 2009.

Baertlein, D., Lindow, S., Panopoulos, N., Lee, S., Mindrinos, M., and Chen, T.: Expression of a bacterial ice nucleation gene in plants, Plant Physiol., 100, 1730-1736, 1992.

Baron, P. and Willeke, K.: Aerosol Measurement - Principles, Techniques and Applications, John Wiley \& Sons, Inc., Toronto, 2 edn., 2001.

Bauer, H., Kasper-Giebl, A., Loflund, M., Giebl, H., Hitzenberger, R., Zibuschka, F., and Puxbaum, H.: The contribution of bacteria and fungal spores to the organic carbon content of cloud water, precipitation and aerosols, Atmos. Res., 64, 109-119, 2002.

Bauer, H., Giebl, H., Hitzenberger, R., Kasper-Giebl, A., Reischl, G., Zibuschka, F., and Puxbaum, H.: Airborne bacteria as cloud condensation nuclei, J. Geophys. Res.-Atmos., 108, 4658, doi:10.1029/2003JD003545, 2003.

Bigg, E., Leck, C., and Tranvik, L.: Particulates of the surface microlayer of open water in the central Arctic ocean in summer, Marine Chem., 91, 131-141, 2004

Borodulin, A., Safatov, A., Shabanov, A., Yarygin, A., Khutorova, O., Belan, B., and Panchenko, M.: Physical characteristics of concentration fields of tropospheric bioaerosols in the South of Western Siberia, J. Aerosol Sci., 36, 785-800, doi:10.1016/j.jaerosci.2004.12.009, 2005.

Bovallius, A., Bucht, B., Roffey, R., and Anas, P.: 3-year investigation of natural airborne bacterial flora at 4 localities in Sweden, Appl. Environ. Microb., 35, 847-852, 1978a.

Bovallius, A., Bucht, B., Roffey, R., and Anas, P.: Long-range air transmission of bacteria, Appl. Environ. Microb., 35, 1231-1232, $1978 b$.

Brock, T., Madigan, M., Martinko, J., and Parker, J.: Mikrobiologie, Spektrum Akademischer Verlag, Heidelberg, 2000.

Burch, M. and Levetin, E.: Effects of meteorological conditions on spore plumes, Int. J. Biometeorol., 46, 107-117, doi:10.1007/s00484-002-0127-1, 2002.

Burrows, S. M., Butler, T., Jöckel, P., Tost, H., Kerkweg, A., Pöschl, U., and Lawrence, M. G.: Bacteria in the global atmosphere - Part 2: Modeling of emissions and transport between different ecosystems, Atmos. Chem. Phys., 9, 9281-9297, doi:10.5194/acp-9-9281-2009, 2009a.

Burrows, S. M., Elbert, W., Lawrence, M. G., and Pöschl, U.: Bacteria in the global atmosphere - Part 1: Review and synthesis of literature data for different ecosystems, Atmos. Chem. Phys., 9, 9263-9280, doi:10.5194/acp-9-9263-2009, 2009 b.
Burrows, S. M., Butler, T., Jöckel, P., Tost, H., Kerkweg, A., Pöschl, U., and Lawrence, M. G.: Bacteria in the global atmosphere - Part 2: Modelling of emissions and transport between different ecosystems, Atmos. Chem. Phys. Discuss., 9, 10829-10881, doi:10.5194/acpd-9-10829-2009, 2009c.

Cagnazzo, C., Manzini, E., Giorgetta, M. A., Forster, P. M. De F., and Morcrette, J. J.: Impact of an improved shortwave radiation scheme in the MAECHAM5 General Circulation Model, Atmos. Chem. Phys., 7, 2503-2515, doi:10.5194/acp-7-2503-2007, 2007.

Chen, M., Jin, L., Sun, Z., Lu, J., Wang, Q., Hu, Q., Sun, R., and Li, Z.: Concentration adn flux of bioaerosol and environmental factors, Prog. Nat. Sci., 11, 681-687, 2001.

Christner, B.C., Rongman, C., Morris, C.E., McCarter, K.S., Foreman, C., Skidmore, M.L., Montross, S.N., and Sands, D.C.: Geographic, seasonal, and precipitation chemistry influence on the abundance and activity of biological ice nucleators in rain and snow, P. Natl. Acad. Sci., 105, 18854-18859 doi:10.1073/pnas.0809816105, 2008.

Dentener, F., Kinne, S., Bond, T., Boucher, O., Cofala, J., Generoso, S., Ginoux, P., Gong, S., Hoelzemann, J. J., Ito, A., Marelli, L., Penner, J. E., Putaud, J.-P., Textor, C., Schulz, M., van der Werf, G. R., and Wilson, J.: Emissions of primary aerosol and precursor gases in the years 2000 and 1750 prescribed data-sets for AeroCom, Atmos. Chem. Phys., 6, 4321-4344, doi:10.5194/acp-64321-2006, 2006.

Diehl, K. and Wurzler, S.: Heterogeneous drop freezing in the Immersion mode: Model Calculations considering soluble and insoluble particles in the drops, J. Atmos. Sci., 61, 2063-2072, 2004.

Diehl, K., Quick, C., Matthias-Maser, S., Mitra, S., and Jaenicke, R.: The ice nucleating ability of pollen Part I: Laboratory studies in deposition and condensation freezing modes, Atmos. Res., 58, 75-87, 2001.

Diehl, K., Matthias-Maser, S., Mitra, S. K., and Jaenicke, R.: The ice nucleating ability of pollen. Part II: Laboratory studies in immersion and contact freezing modes., Atmos. Res., 61, 125-133, 2002.

Diehl, K., Simmel, M., and Wurzler, S.: Numerical sensitivity studies on the impact of aerosol properties and drop freezing modes on the glaciation, microphysics, and dynamics of clouds, J. Geophys. Res.-Atmos., 111, D07202, doi:10.1029/2005JD005884, 2006.

Diehl, K. and Wurzler, S.: Air parcel model simulations of a convective cloud: Bacteria acting as immersion ice nuclei, Atmos. Environ., 44, 4622-4628, 2010.

DiGiorgio, C., Krempff, A., Guiraud, H., Binder, P., Tiret, C., and Dumenil, G.: Atmospheric pollution by airborne microorganisms in the city of Marseilles, Atmos. Environ., 30, 155-160, 1996.

Ebert, M., Weinbruch, S., Rausch, A., Gorzawski, G., Hoffmann, P., Wex, H., and Helas, G.: Complex refractive index of aerosols during LACE 98 as derived from the analysis of individual particles, J. Geophys. Res., 107, 8121, doi:10.1029/2000JD000195, 2002.

Fang, Z., Ouyang, Z., Zheng, H., Wang, X., and Hu, L.: Culturable airborne bacteria in outdoor environments in Beijing, China, Microb. Ecol., 54, 487-496, doi:10.1007/s00248-007-9216-3, 2007.

Fahlgren, C., Hagström,Å., Nilsson, D., and Zweifel, U. L.: Annual Variations in the Diversity, Viability, and Origin of Airborne Bac- 
teria, Appl. Environ. Microbiol., 76, 3015-3025, 2010.

Fenn, R. W., Shettle, E. P., Hering, W. S., and Johnson, R. W.: Atmospheric optical properties and meteorological conditions, Atmos. Environ., 15, 1911-1918, 1981.

Forster, P., Ramaswamy, V., Artaxo, P., Berntsen, T., Betts, R., Fahey, D., Haywood, J., Lean, J., Lowe, D., Myhre, G., Nganga, J., Prinn, R., Raga, G., Schulz, M., and Dorland, R. V.: Changes in Atmospheric Constituents and in Radiative Forcing, in: Climate Change 2007: The Physical Science Basis. Contribution of Working Group I to the Fourth Assessment Report of the Intergovernmental Panel on Climate Change, edited by Solomon, S., Qin, D., Manning, M., Chen, Z., Marquis, M., Averyt, K., Tignor, M., and Miller, H., Cambridge University Press, Cambridge, United Kingdom and New York, NY, USA, 2007.

Graham, B., Guyon, P., Maenhaut, W., Taylor, P. E., Ebert, M., Matthias-Maser, S., Mayol-Bracero, O. L., Godoi, R. H. M., Artaxo, P., Meixner, F. X., Lima Moura, M. A., Eça D’Almeida Rocha, C. H., Van Grieken, R., Glovsky, M. M., Flagan, R. C., and Andreae, M. O.: Composition and diurnal variability of the natural Amazonian aerosol, J. Geophys. Res., 108, 47645, doi:10.1029/2003JD004049, 2003.

Greenwald, T. J., Stephens, G. L., Vonder Haar, T. H., and Jackson, D. L.: A physical retrieval of cloud liquid water over the global oceans using Special Sensor Microwave/Imager (SSM/I) observations, J. Geophys. Res., 98, 18471-18488, 1993.

Griffin, D.: Atmospheric movement of microorganisms in clouds of desert dust and implications for human health, Clin. Microbiol. Rev., 20, 459-477, doi:10.1128/CMR.00039-06, 2007.

Gruber, S., Matthias-Maser, S., Brinkmann, J., and Jaenicke, R.: Vertical Distribution of Biological Aerosol Particles above the North Sea, J. Aerosol Sci., 29, S771, 1998.

Grützun, V., Knoth, O., and Simmel, M.: Simulation of the influence of aerosol particle characteristics on clouds and precipitation with LM-SPECS: Model description and first results, Atmos. Res., 90, 233-242, doi:10.1016/j.atmosres.2008.03.002, 2008.

Hahn, C., Warren, S., and London, J.: The effect of moonlight on observation of cloud cover at night, and application to cloud climatology, J. Clim., 8, 1429-1446, 1995.

Han, Q., Rossow, W. B., Chou, J., and Welch, R. M.: Global variation of column droplet concentration in low-level clouds, Geophys. Res. Lett., 25, 1419-1422, 1998.

Hinds, W. C.: Bioaerosols, Aerosol Tech., pp. 394-401, book chapter 19, 1999.

Hirano, S. S. and Upper, C. D.: Bacteria in the leaf ecosystem with emphasis on Pseudomonas syringae - a pathogen, ice nucleus, and epiphyte, Microbiol. Mol. Biol. R., 64, p. 624, 2000.

Hoose, C., Lohmann, U., Erdin, R., and Tegen, I.: Global Influence of Dust Mineralogical Composition on Heterogeneous Ice Nucleation in Mixed-Phase Clouds, Environ. Res. Lett., 3, 025003, doi:10.1088/1748-9326/3/2/025003, 2008.

Hoose, C., Kristjánsson, J. E., Chen, J.-P., and Hazra, A.: A classical-theory-based parameterization of heterogeneous ice nucleation by mineral dust, soot and biological particles in a global climate model, J. Atmos. Sci., 67, 2483-2503, 2010 a.

Hoose, C., Kristjánsson, J. E., and Burrows, S.: How important is biological ice nucleation in clouds on a global scale?, Environ. Res. Lett., 5, 024009, doi:10.1088/1748-9326/5/2/024009, 2010 b.

Horner-Devine, M. C., Carney, K. M., and Bohannan B. J. M.: An ecological perspective on bacterial biodiversity, Proc. R. Soc.
Lond. B, 271, 113-122, 2004.

Huffman, G., Adler, R., Arkin, P., Chang, A., Ferraro, R., Gruber, A., Janowiak, J., McNab, A., Rudolf, B., and Schneider, U.: The Global Precipitation Climatology Project (GPCP) Combined Precipitation Dataset, B. Am. Meteorol. Soc., 78, 5-20, 1997.

Iannone, R., Chernoff, D. I., Pringle, A., Martin, S. T., and Bertram, A. K.: The ice nucleation ability of one of the most abundant types of fungal spores found in the atmosphere, Atmos. Chem. Phys., 11, 1191-1201, doi:10.5194/acp-11-1191-2011, 2011.

Jacobson, M. and Streets, D.: Influence of future anthropogenic emissions on climate, natural emissions, and air quality, J. Geophys. Res.-Atmos., 114, D08118, doi:10.1029/2008JD011476, 2009.

Jaenicke, R., Matthias-Maser, S., and Gruber, S.: Omnipresence of biological material in the atmosphere, Environ. Chem., 4, 217, 2007.

Jones, A. M. and Harrison, R. M.: The effects of meteorological factors on atmospheric bioaerosol concentrations - a review, Sci. Total Environ., 326, 151-180, 2004.

Jones, S., Newton, R., and McMahon, K.: Potential for atmospheric deposition of bacteria to influence bacterioplankton communities, FEMS Microb. Ecol., 64, 388-394, doi:10.1111/j.15746941.2008.00476.x, 2008.

Kärcher, B. and Lohmann, U.: A parameterization of cirrus cloud formation: Homogeneous freezing including effects of aerosol size, J. Geophys. Res., 107, 4698, doi:10.1029/2001JD001429, 2002.

Kellog, C. and Griffin, D.: Aerobiology and the global transport of desert dust, Trends. Ecol. Evol., 21, 638-644, 2006.

Kelly, C. and Pady, S.: Microbiological studies of air masses over Montreal during 1950 and 1951, Can. J. Botany, 32, 591-600, 1954.

Kiehl, J. T. and Trenberth, K.: Earth's annual global mean energy budget, B. Am. Meteorol. Soc., 78, 197-208, 1997.

Levin, Z. and Yankofsky, S.: Contact versus immersion freezing of freely suspended droplets by bacterial ice nuclei. J. Clim. Appl. Meteorol., 22, 1964-1966, 1983.

Levin, Z. and Yankofsky, S.: Lecture notes in physics, atmospheric aerosols and nucleation, chap. Ice nuclei of biological origin, pp. 620-633, Springer, 1988.

Lin, H. and Leaitch, W. R.: Development of an in-cloud aerosol activation parameterization for climate modelling. Proc. WMO Workshop on Measurement of Cloud Properties for Forecasts of Weather, Air Quality and Climate, Geneva, Switzerland, World Meteorology Organization, 328-355, 1997.

Lin, S. and Rood, R.: Multidimensional flux-form semi-Lagrangian transport schemes, Mon. Weather Rev., 124, 2046-2070, 1996.

Lindemann, J. and Upper, C.: Aerial dispersal of epiphytic bacteria over bean-plants, Appl. Environ. Microb., 50, 1229-1232, 1985.

Lindemann, J., Constantinidou, H., Barchet, W., and Upper, C.: Plants as sources of airborne bacteria, including ice nucleationactive bacteria, Appl. Environ. Microb., 44, 1059-1063, 1982.

Lindow, S. and Andersen, G.: Influence of immigration on epiphytic bacterial populations on navel orange leaves, Appl. Environ. Microb., 62, 2978-2987, 1996.

Lohmann, U. and Diehl, K.: Sensitivity studies of the importance of dust ice nuclei for the indirect aerosol effect on stratiform mixedphase clouds, J. Atmos. Sci., 63, 968-982, 2006. 
Lohmann, U. and Feichter, J.: Global indirect aerosol effects: a review, Atmos. Chem. Phys., 5, 715-737, doi:10.5194/acp-5-7152005, 2005.

Lohmann, U. and Hoose, C.: Sensitivity studies of different aerosol indirect effects in mixed-phase clouds, Atmos. Chem. Phys., 9, 8917-8934, doi:10.5194/acp-9-8917-2009, 2009.

Lohmann, U., Stier, P., Hoose, C., Ferrachat, S., Kloster, S., Roeckner, E., and Zhang, J.: Cloud microphysics and aerosol indirect effects in the global climate model ECHAM5-HAM, Atmos. Chem. Phys., 7, 3425-3446, doi:10.5194/acp-7-3425-2007, 2007.

Maki, L., Galyan, E., Changchi, M., and Caldwell, D.: Ice nucleation induced by Pseudomonas Syringae, Appl. Microbiol., 28, 456-459, 1974.

Matthias-Maser, S. and Jaenicke, R.: The size distribution of primary biological aerosol particles with radii $>0.2 \mu \mathrm{m}$ in an urban/rural influenced region, Atmos. Res., 39, 279-286, 1995.

McNamara, C. J., Lemke, M. J., and Leff, L. G.: Characterization of hydrophobic stream bacteria based on adhesion to n-Octane, Ohio J. Sci., 97, 59-61, 1997.

Mlawer, E., Taubman, S., Brown, P., Iacono, M., and Clough, S.: Radiative transfer for inhomogeneous atmospheres: RRTM, a validated correlated-k model for the longwave, J. Geophys. Res.Atmos., 102, 16663-16682, 1997.

Michaud, A. B., Sands, D. C., Dore, J. E., Leslie, D., Lyons, W. B., and Priscu, J. C.: The Role of Ice Nucleating Bacteria in Hailstone Formation. 11th General Meeting of the American Society for Microbiology, New Orleans, 2011.

Möhler, O., Georgakopoulos, D. G., Morris, C. E., Benz, S., Ebert, V., Hunsmann, S., Saathoff, H., Schnaiter, M., and Wagner, R.: Heterogeneous ice nucleation activity of bacteria: new laboratory experiments at simulated cloud conditions, Biogeosciences, 5, 1425-1435, doi:10.5194/bg-5-1425-2008, 2008.

Morcrette, J., Clough, S., Mlawer, E., and Iacono, M.: Impact of a validated radiative transfer scheme, RRTM, on the ECMWF model climate and 10-day forecasts, Tech. rep., ECMWF, Reading, UK, 1998.

Morris, C., Georgakopoulos, D., and Sands, D.: Ice nucleation active bacteria and their potential role in precipitation, J. Phys. IV, 121, 87-103, 2004.

Morris, C. E., Sands, D. C., Bardin, M., Jaenicke, R., Vogel, B., Leyronas, C., Ariya, P. A., and Psenner, R.: Microbiology and atmospheric processes: research challenges concerning the impact of airborne micro-organisms on the atmosphere and climate, Biogeosciences, 8, 17-25, doi:10.5194/bg-8-17-2011, 2011.

Mouli, P., Mohan, S., and Reddy, S.: Assessment of microbial (bacteria) concentrations of ambient air at semi-arid urban region: influence of meteorological factors, Appl. Ecol. Env. Res., 3, 139149, 2005.

Negrin, M., Del Panno, M., and Ronco, A.: Study of bioaerosols and site influence in, the La Plata area (Argentina) using conventional and DNA (fingerprint) based methods, Aerobiologia, 23, 249258, doi:10.1007/s10453-007-9069-8, 2007.

Nordeng, T. E.: Extended versions of the convective parameterization scheme by ECMWF and their impact on the mean and transient activity of the model in the tropics, Tech. rep., ECMWF, Reading, UK, 1994.

Olson, J. S.: Digital Raster Data on a 10-minute Cartesian Orthonormal Geodetic 1080x2160 grid, in: Global Ecosystems Database,
Version 2.0, Boulder, CO: National Geophysical Data Center, 1992.

Pastuszka, J., Paw, U., Lis, D., Wlazlo, A., and Ulfig, K.: Bacterial and fungal aerosol in indoor environment in Upper Silesia, Poland, Atmos. Environ., 34, 3833-3842, 2000.

Phillips, V. T. J., Andronache, C., Christner, B., Morris, C. E., Sands, D. C., Bansemer, A., Lauer, A., McNaughton, C., and Seman, C.: Potential impacts from biological aerosols on ensembles of continental clouds simulated numerically, Biogeosciences, 6 , 987-1014, doi:10.5194/bg-6-987-2009, 2009.

Pitter, R.L. and Pruppacher, H.R.: A wind tunnel investigation of freezing of small water drops falling at terminal velocity in air, Q. J. Roy. Meteor. Soc., 99, 540-550, 1973.

Pouleur, S., Richard, C., Martin, J. G., and Antoun, H.: Ice nucleation activity in Fusarium Acuminatum and Fusarium Avenaceum, Appl. Environ. Microb., 58, 2960-2964, 1992.

Pratt, K., DeMott, P., French, J., Wang, Z., Westphal, D., Heymsfield, A., Twohy, C., Prenni, A., and Prather, K.: In situ detection of biological particles in cloud ice-crystals, Nat. Geosci., 2, 397400, doi:10.1038/NGEO521, 2009.

Prospero, J., Blades, E., Mathison, G., and Naidu, R.: Interhemispheric transport of viable fungi and bacteria from Africa to the Caribbean with soil dust, Aerobiologia, 21, 1-19, doi:10.1007/s10453-004-5872-7, 2005.

Raddatz, T. J., Reick, C. H., Knorr, W., Kattge, J., Roeckner, E., Schnur, R., Schnitzler, K. G., Wetzel, P., and Jungclaus, J.: Will the tropical land biosphere dominate the climate-carbon cycle feedback during the twenty-first century?, Clim. Dyn., 29, 565574, doi:10.1007/s00382-007-0247-8, 2007.

Roeckner, E., Bäuml, G., Bonaventura, L., Brokopf, R., Esch, M., Giorgetta, M., Hagemann, S., Kirchner, I., Kornblueh, L., Manzini, E., Rhodin, A., Schlese, U., Schulzweida, U., and Tompkins, A.: The atmospheric general circulation model ECHAM5: Part I: Model description, Tech. Rep. 349, Max Planck Institute for Meteorology, Hamburg, 127 pp., 2003.

Rosas, I., Yela, A., and Santos-Burgoa, C.: Occurence of airborne enteric bacteria in Mexico City, Aerobiologia, 10, 39-45, 1994.

Rossow, W. B. and Schiffer, R. A.: Advances in understanding clouds from ISCCP, B. Am. Meteorol. Soc., 80, 2261-2287, 1999.

Rüden, H., Thofern, E., Fischer, E., and Mihm, U.: Airborne microorganisms - Their occurence, distribution and dependence on environmental factors - especially on organic compounds of air pollution, Pure Appl. Geophys., 116, 335-350, 1978.

Sands, D., Langhans, V., Scharen, A., and DeSmet, G.: The association between bacteria and rain and possible resultant meteorological implications, Időjárás, 86, 148-152, 1982.

Schlesinger, P., Mamane, Y., and Grishkan, I.: Transport of microorganisms to Israel during Saharan dust events, Aerobiologia, 22, 259-273, doi:10.1007/s10453-006-9038-7, 2006.

Schnell, R. and Vali, G.: Atmospheric Ice Nuclei from Decomposing Vegetation, Nature, 236, 163-165, 1972.

Schnell, R. and Vali, G.: World-wide source of leaf derived freezing nuclei, Nature, 246, 212-213, 1973.

Schnell, R. and Vali, G.: Biogenic ice nuclei. Part I. Terrestrial and marine sources, J. Atmos. Sci., 33, 1554-1564, 1976.

Schulz, M., Textor, C., Kinne, S., Balkanski, Y., Bauer, S., Berntsen, T., Berglen, T., Boucher, O., Dentener, F., Guibert, S., Isaksen, I. S. A., Iversen, T., Koch, D., Kirkevåg, A., Liu, X., Monta- 
naro, V., Myhre, G., Penner, J. E., Pitari, G., Reddy, S., Seland, $\varnothing$., Stier, P., and Takemura, T.: Radiative forcing by aerosols as derived from the AeroCom present-day and pre-industrial simulations, Atmos. Chem. Phys., 6, 5225-5246, doi:10.5194/acp-65225-2006, 2006.

Seinfeld, J. H. and Pandis, S.: Atmos. Chem. Phys., John Wiley \& Sons, Inc., 2006.

Shaffer, B. and Lighthart, B.: Survey of culturable airborne bacteria at four diverse location in Oregon: urban, rural, forest and coastal, Microb. Ecol., 34, 167-177, 1997.

Lighthart, B.: The ecology of bacteria in the alfresco atmosphere, FEMS Microbiology Ecology, 23, 263-274, 1997.

Simmons, A. J. and Gibson, J. K.: The ERA-40 project plan, Tech. rep., ECMWF, Shinfield Park, Reading, UK, 2000.

Spichtinger, P. and Cziczo, D. J.: Impact of heterogeneous ice nuclei on homogeneous freezing events in cirrus clouds, J. Geophys. Res., 115, D14208, doi:10.1029/2009JD012168, 2010.

Stier, P., Feichter, J., Kinne, S., Kloster, S., Vignati, E., Wilson, J., Ganzeveld, L., Tegen, I., Werner, M., Balkanski, Y., Schulz, M., Boucher, O., Minikin, A., and Petzold, A.: The aerosol-climate model ECHAM5-HAM, Atmos. Chem. Phys., 5, 1125-1156, doi:10.5194/acp-5-1125-2005, 2005.

Storelvmo, T., Kristjánsson, J., and Lohmann, U.: Aerosol influence on mixed-phase clouds in CAM-Oslo, J. Atmos. Sci., 65, 32143230, doi:10.1175/2008JAS2430.1, 2008.

Stubenrauch, C. and Kinne, S.: Assessment of Global Cloud Climatologies, Tech. rep., GEWEX news, 2009.

Sun, J. and Ariya, P.: Atmospheric organic and bio-aerosols as cloud condensation nuclei (CCN): A review, Atmos. Environ., 40, 795820, doi:10.1016/j.atmosenv.2005.05.052, 2006.

Sun, J., Ariya, P. A., Leighton, H. G., and Yau, M. K.: Mystery of ice multiplication in warm-based precipitating shallow cumulus clouds, Geophys. Res. Lett., 37, L10802, doi:10.1029/2010GL042440, 2010.

Tiedtke, M.: A Comprehensive Mass Flux Scheme for Cumulus Parameterization in Large-Scale Models, Mon. Weather Rev., 117, 1779-1800, 1989.

Tilley, R., Eamus, D., and Ho, J.: Background bioaerosol and aerosol at two sites in northern Australia: Preliminary measurements, Tech. rep., DSTO Aeronautical and Maritime Research Laboratory, Victoria, Australia, 2001.

Timmreck, C. and Schulz, M.: Significant dust simulation differences in nudged and climatological operation mode of the AGCM ECHAM, J. Geophys. Res., 109, D13202, doi:10.1029/2003JD004381, 2004.
Tong, Y. and Lighthart, B.: The annual bacterial particle concentration and size distribution in the ambient atmosphere in a rural area of the Willamette valley, Oregon, Aerosol. Sci. Tech., 32, 393-403, 2000.

Vignati, E., Wilson, J., and Stier, P.: M7: An efficient size-resolved aerosol microphysics module for large-scale aerosol transport models, J. Geophys. Res., 109, D22202, doi:10.1029/2003JD004485, 2004.

Vlodavets, V. and Mats, L.: The influence of meteorological factors on the microflora of the atmospheric air in Moscow, J. Microbiol., 59, 539-544, 1958.

von Blohn, N., Mitra, S., Diehl, K., and Borrmann, S.: The ice nucleating ability of pollen: Part III: New laboratory studies in immersion and contact freezing modes including more pollen types, Atmos. Res., 78, 182-189, doi:10.1016/j.atmosres.2005.03.008, 2005.

Šantl Temkiv, T., Gosewinkel Karlson, U., Finster, K., and Munk Hansen, B.: The diversity and proportion of ice nucleation active bacteria in rain and their ability to produce extracellular ice nucleation active particles, in: 18th International Conference on Nucleation and Atmospheric. Aerosols (ICNAA), Prague, Czech Republic, edited by: Smolík, J. and O’Dowd, C., 2009.

Wainwright, M., Wickramasinghe, N. C., Narlikar, J. V., and Rajaratnam, P.: Microorganisms cultured from stratospheric air samples obtained at $41 \mathrm{~km}$, FEMS Microbiol. Lett., 218, 161$165,2003$.

Weng, F. and Grody, N. C.: Retrieval of cloud liquid water using the special sensor microwave imager (SSM/I), J. Geophys. Res., 99, 25535-25551, 1994.

Wentz, F. J.: A well-calibrated ocean algorithm for SSM/I, J. Geophys. Res., 102, 8703-8718, 1997.

Wyatt, P. J.: Cell wall thickness, size distribution, refractive index ratio and dry weight content of living bacteria (Staphylococcus aureus), Nature, 226, 277-279, doi:10.1038/226277a0, 1970.

Yankofsky, S., Levin, Z., Bertold, T., and Sandlerman, N.: Some Basic Characteristics of Bacterial Freezing Nuclei, J. Appl. Meteorol., 20, 1013-1019, 1981a.

Yankofsky, S., Levin, Z., and Moshe, A.: Association with citrus of ice-nucleating bacteria and their possible role as causative agents of frost damage, Curr. Microbiol., 5, 213-217, 1981 b. 